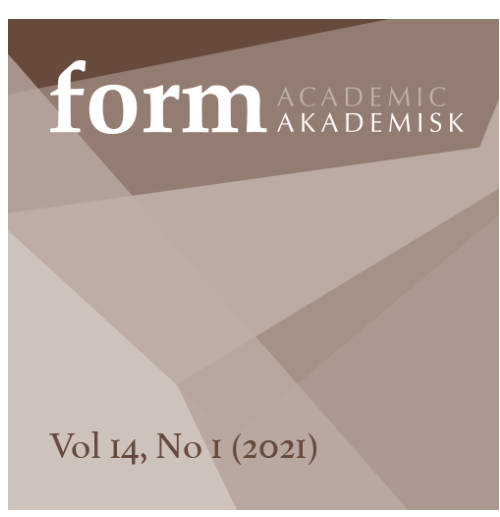

\title{
Spesialrom for Kunst og håndverk i grunnskolen
}

\author{
- analyse av retningslinjer 1889-1992
}

\begin{abstract}
SAMMENDRAG
I dag bestemmer den enkelte kommune hvordan spesialrom skal utformes ut fra gjeldende læreplan for grunnskolen og innenfor rammene av opplæringsloven, plan og bygningsloven samt byggetekniske forskrifter. Før 1983 fantes det imidlertid nasjonale retningslinjer for utforming av spesialrom i den norske grunnskolen. Jeg har anvendt kritisk diskursanalyse og analysert slike retningslinjer fra 1889 til 1992. Retningslinjene i denne perioden skifter fra beordringer om spesialrom for læring av spesifikke håndverk (1889-1960) til beordringer som ideologisk understøtter rom for fri utfoldelse av formings-aktiviteter og selvutvikling (1960-1992). De analyserte tekstene før 1960 inneholder ikke forsknings-baserte begrunnelser for hvordan spesialrom skal eller bør være, beordringene synes heller å lene seg på tradisjon og erfaring. Etter 1960 begrunnes beordringene først og fremst ut fra teori; nye ideer og tanker om faget Forming. Dette skiftet har også økonomiske motiver.
\end{abstract}

\section{Nøkkelord:}

spesialrom for Kunst og håndverk, læreplaner, nasjonale retningslinjer, beordringer, råd og veiledninger.

\section{INNLEDNING}

I min mangeårige praksis som lærer og lærerutdanner, har jeg erfart at spesialrommene for faget Kunst og håndverk i nye skoleanlegg ikke tilrettelegger godt nok for arbeid med harde og plastiske materialer. Det finnes ikke konkrete krav til størrelse, eller type verktøy eller spesialrom verken i læreplanene fra 1997 (L97), 2006 (LK06) eller i 2020 (LK20). Materialene presiseres i LK20 på 4. trinn til å være tre, leire og tekstil, og de presiseres på 7. trinn til å være harde-, myke og plastiske materialer (Utdanningsdirektoratet, 2020). Det er ut fra dette opp til den enkelte skoleeier/rektor/lærer å avgjøre hva som trengs av rom, materialer, maskiner, verktøy og utstyr.

Etter innføringen av L97 har det kommet flere lærebøker i Kunst og håndverk, som for eksempel Akantus (Dahl \& Johansen, 2006) eller Mønster på vandring (Håberg et al, 1997), hvor læreplanen konkretiseres med faginnhold og forslag til praktiske oppgaver. Ulike materialer, verktøy og teknikker vises, også i lærerveiledningene, men heller ikke her finnes beskrivelser av, eller begrunnelser for hvordan, 
spesialrom for faget kan, bør eller må være. I boka Kunst og håndverk - hva og hvorfor, beskriver forfatterne det fysiske miljøet i kapittelet Det kreative miljøet (Haabesland \& Vavik, 2004, s. 225-226). Her handler det først og fremst om trivsel og stimulering av kreativitet. Et eksempel på romorganisering vises i en figur med allrom og verksteder/verkstedplasser (s. 226). Boka Fagdidaktikk for Kunst og håndverk. I går, i dag, i morgen (Nielsen, 2019) trekker heller ikke inn utformingen av spesialrom. Flere forskere har vært opptatt av verksteder for Kunst og håndverk i grunnskolen (Underthun, 2003; Hansen, 2015; Tvedt, 2018). De beskriver og drøfter praksis, men det finnes lite relevant litteratur som beskriver, og ikke minst begrunner hvordan, spesialrom for faget kan, bør eller må være.

\section{PROBLEMSTILLING OG METODE}

Min overordnede problemstilling er å undersøke og drøfte hva som kan ligge til grunn for utforming av spesialrom for det som i dag er faget Kunst og håndverk i grunnskolen. For å kunne forstå dagens praksis har jeg valgt å studere krav til spesialrom i et historisk perspektiv. Jeg stiller følgende spørsmål: Hvordan har myndighetenes retningslinjer til utforming av spesialrom for det som i dag er faget Kunst og håndverk utviklet seg i perioden fra 1889 til 1992?

Med utforming av spesialrom velger jeg å se på retningslinjer til utformingen av både det fysiske rommet og interiøret med læremidler, maskiner, materialer, verktøy og utstyr. Tidsperioden er begrunnet $\mathrm{i}$ at de tidligste retningslinjene for spesialrom for faget finnes i de første folkeskolelovene fra 1889. Året 1992 markerer nedleggelsen av Grunnskolerådet og dermed også en ny praksis med lokalt utformede retningslinjer. Etter denne perioden ble Reform 97 utviklet, og faget skiftet navn fra Forming til Kunst og håndverk med Læreplanen (L97) som ble innført i 1997 (KUF, 1997).

Jeg har valgt å søke etter nasjonale retningslinjer i folkeskolelovene, læreplaner, offentlige utredninger (NOU) samt veiledere og andre tekster skrevet av Grunnskolerådet (tidligere Folkeskolerådet) som var Kirke- og undervisningsdepartementets rådgivende organ i deler av denne perioden. For å finne det historiske materialet har jeg valgt å benytte meg av søk på Nasjonalbibliotekets nettbibliotek hvor eldre lover og læreplaner, retningslinjer og innstillinger ligger digitalisert. Jeg har benyttet søkeord som læreplan, NOU og Grunnskolerådet gjerne kombinert med ord som sløyd, haandarbeid, tegning og forming. Ved interessante treff har jeg lett etter henvisninger og referanser og nøstet videre ved å lete etter retningslinjer for spesialrom ved hjelp av søkeord som spesialrom, undervisningsrom og rom for læring.

I søkearbeidet dukket det opp et kompendium fra et kurs i skolebygging på Norges Tekniske Høgskole (NTH) i 1958 (Dalaker \& Bastiansen, 1959). Selv om tekstene i kompendiet ikke faller innenfor avgrensningen nasjonale retningslinjer, har jeg likevel valgt å presentere tanker og ideer fra dette kompendiet fordi kurset synes å samle både sentrale aktører innenfor skolefeltet og viktige arkitekter i en periode hvor det skulle bygges mange nye skoler i den kraftig voksende utdanningssektoren i etterkrigstiden. Både rektor Torleiv Hellkås ved Statens sløyd-og teiknelærarskole (SSTL) på Notodden og rektor Tønnes Sirevåg, leder for arbeidet med Læreplanen for forsøk med 9-årig skole (KUD, 1960), legger i dette kompendiet fram refleksjoner over spesialrom til det nye faget Forming. Her har også sivilarkitekt Olav Selvåg et innlegg hvor han presenterer ideer om effektivisering av skolearealene, blant annet om hvordan de dyre sløydsalene kan gjøres mindre. Det er derfor rimelig å anta at tanker og ideer fra dette kurset både har vært representative og retningsgivende for utformingen av spesialrom i årene som fulgte.

De historiske retningslinjene vil bli analysert med utgangspunkt i kritisk diskursanalyse (Skrede, 2017). Jeg har valgt å se på beordringer; hvordan kravene stilles med hensyn til deontisk modalitet; om de er beordret som 1) pålegg (f.eks. skal/må), som 2) anbefaling (f.eks. kan/bør/ønskelig/helst) eller som 3) forbud (f.eks. skal ikke) (Fairclough, 2003, s. 168). Bruk av termen modalt beordret med verbene kan/ $b \varnothing r / \varnothing n s k e l i g / h e l s t$ kan oppfattes som en motsigelse, fordi verbene antyder en anbefaling mens beordring oppfattes som et påbud eller et forbud. Jeg har derfor valgt å forsterke meningsinnholdet med det forklarende ordet anbefaling. For å gjøre beordringene tydelige har jeg i den videre teksten, også i siteringene, valgt å framheve modaliteten med kursiv. 
Jeg har valgt å gjøre analysen av vedtatte læreplaner, veiledere og andre retningslinjer med utgangspunkt i Goodlads (1979) læreplanteori og Nielsens videreutvikling av denne (2019). Jeg har valgt å drøfte disse retningslinjene i lys av ideologisk formulerte innspill og hvordan disse har blitt tolket. Jeg benytter derfor begrepene vedtatt læreplan, ideologisk nivå og tolkningsnivå (Nielsen, 2019). Fordi noen av retningslinjene berører romproblematikken betydelig mer enn andre, vil analysene også ha ulikt omfang. Av hensyn til denne artikkelens lengde velger jeg bort å unders $\varnothing$ ke hvordan spesialrommene faktisk ble utformet i skolen, det som i en slik kontekst kan betegnes som gjennomført nivå.

\section{FERDIGHETSFAGENE SL $\varnothing$ YD, HÅNDARBEID OG TEGNING De første folkeskolelovene}

Ferdighetsfagene Håndarbeid for jenter og Håndarbeid for gutter ble innført som fag i skolen med folkeskolelovene av 1889. I begge lovene er beordringene til innredning og læremidler generelle: «Hver skole skal være forsynet med forn $\varnothing$ dendt Indbo og Legeplads samt de Læremidler, som tiltrenges til fælles Brug ved Undervisningen» (Lov om Folkeskolen paa landet, 1889, s. 430; Lov om Folkeskolen i Køpstederne, 1889, s. 441). I Lov om Folkeskolen paa landet er ikke Håndarbeid og Tegning obligatorisk, men kan velges dersom omstændighederne tilsteder (tillater) det (s. 429). Hvilke omstendigheter som er gyldige beskrives ikke, men det kan tenkes at elevantall, tilgjengelige lærere og undervisningsrom samt $\emptyset$ konomi kan være slike omstendigheter. En grunn til at håndarbeidsfagene ikke var obligatoriske på landet, kan være at det her fortsatt fantes en tradisjon for at barna lærte nødvendig håndverk hjemme (Nielsen, 2019, s. 53). I Folkeskoleloven for byene finner vi derimot at Håndarbeid er obligatorisk for jenter i årsklassene 7-12 og at guttene skal ha sløyd (Haandarbeid) på årstrinnene 10-12, men kun på de $\varnothing$ vrige årsklassene dersom skolestyret bestemmer det i skoleplanen (s. 439-440). Tegning er obligatorisk i byene på årstrinnene 10-12 og 12-14 dersom skolestyret bestemmer det (s. 439-440).

\section{Normalplanen for landsfolkeskolen 1922 (N22)}

I faget Tegning skal elevene utvikle iakttakelsesevne og øve seg i å gjengi det de ser i tegning (KUD, 1922, s. 61). Under overskriften Vink (veiledning til læreren) pekes det på at det trengs ting som eleven selv skal iaktta (s. 61) og «Blir det tegnet etter små modeller, må det være mange av dem til klassen» (s. 62) og videre at «De modellene som trengs, må fins ved alle skoler» (s. 63). På sidene 63-66 listes det opp hele 99 ulike eksempler på ting i 2- og 3-dimensjoner sortert ut fra vanskelighetsgrad under ulike trinn. Det beordres videre at det bør brukes fargestifter til fargelegging i småklassene, mens det fra 5 . klasse og oppover, foruten fargestifter og kullstifter også bør brukes vannfarger (KUD, 1922, s. 62). At det må finnes en slik mengde med modeller, og at det bør finnes tegne- og maleutstyr, vil kreve en eller annen form for lagerplass. Pensler og vannfarger krever tilgang til en vaskekum. Det er mulig å tenke seg at undervisningen kan foregå i et ordinært undervisningsrom. Planen har ingen beordringer om utforming av spesialrom for faget Tegning.

Håndarbeid for jenter har som mål «å vekke arbeidslysten hos elevene og opøve deres skjønhets- og formsans og gi dem praktisk arbeidsøving, så de mest mulig kan bli selvhjulpne med å lage klærne sine og holde dem i stand» (KUD, 1922, s. 80). Etter målet beskrives undervisningen. Læremidler, utstyr og verktøy som beordres, nevnes, eller som kan utledes, er: godkjent håndbok, modeller, tavle, syramme, grove strikkepinner, heklenål, nål og tråd, saks, målebånd, skredderkritt og blyant (s. 80). Ut fra verktøyet og utstyret kan vi utlede at det trengs stoffer, papir, mønsterpapir samt strikke- og heklegarn. I N22 kan det med andre ord i beskrivelsene av undervisningen utledes hva som er relevante materialer, verktøy og utstyr for faget Håndarbeid for jenter. Symaskin beordres som et unntak med påbud: «Symaskiner må det være ved alle skoler» (s. 80). Hvor mange presiseres ikke.

Sløyd har som mål «Å lære elevene å bruke det vanligste verktøy og å gi dem opøving i å lage enkle ting av tre» (KUD, 1922, s. 75). Hva som menes med de vanligste verkt $\varnothing y$ beskrives ikke, men dette kan utledes på samme side under Plan, hvor det listes opp ulike teknikker på ulike skoleår: spikking, saging, høvling, boring (4. skoleåret), rundhøvling, filing, saging efter buet linje, kantfiling (5. skoleåret), sammensetning med spiker og skrue (6. skoleåret) samt innfelling, korsfelling, grading, sinking osv., så langt en kan rekke (7. skoleåret). Under Vink (s. 75-79) beordres, nevnes, eller kan det utledes, at det 
trengs verktøy, utstyr og læremidler som bryne, kniv, høvel, pusshøvel, høvelbenk, klubbe, hoggjern, sag, fil, sandpapir, slipestein og sløydmodeller. Under Verktøiet beskrives i presens for høvelbenken; «Lys forfra og fra siden. Arbeidsplass 70 à $80 \mathrm{~cm}$. bak benken og 40 à 50 til siden» (s.78). Under Orden beordres gjennomført renslighet og orden. Det er altså nødvendig med rengjøringsutstyr og ordnede oppbevaringsmuligheter for materialer, verktøy og utstyr. Dette begrunnes både ut fra sanitære og pedagogiske hensyn (uorden virker rent demoraliserende). Deretter beordres det at alle verktøy må ha sin faste plass, «[...] enten i skaprum, reoler eller ved verktøybrettet på benken» (s. 78). Under punkt 5 ser vi at sløydundervisningen både kan gis i et sammenhengende kurs og som en eller to timers $\varnothing$ kter $i$ følge med undervisningen ellers.

Den siste ordningen er pedagogisk sett den beste; men da må sløiden ha et eget lokale. Dette bør ha 9 $\mathrm{m}^{3}$ luft for hver elev. Høiden $b \varnothing r$ være ca. $3 \mathrm{~m}$., gulvarealet pr. benk $3 \mathrm{~m}^{2}$. Til dette kommer for hele partiet plass for skap, slipestein, bord for læreren. hoggestabbe o. s. v. Lysflaten bør ikke være under 1/5 av gulvflaten. Lys forfra og fra høire side.

Et særskilt rum - helst ved siden av sløidlokalet - til å gjemme materialer i (4 à $5 \mathrm{~m}$. X 3 m.) og med plass til skap for ting som er ferdige, eller som er under arbeid.

(KUD, 1922, s. 79)

Deretter pekes det på at sløydlokalet må være tørt og ha god ventilasjon. I faget Sløyd beskrives, nevnes, og beordres det her både modalt som anbefalinger og med påbud ulike typer teknikker, verktøy og utstyr. Spesialrom påbys dersom faget gis i følge med annen undervisning og videre anbefales det modalt hvordan dette $b \varnothing r$ være. Alternativt kan undervisningen gis som et sammenhengende kurs hvor det er rimelig å tolke at dette gis i spesialrom for sløyd sentralt. At planen har navnet Normalplanen er også med på å underbygge at beskrivelsene av undervisningen i presens er i henhold til det som skal være normalt.

Hverken skolelovene fra 1896, eller Normalplanen fra 1922 førte til at alle skoler fikk spesialrom. Skolestatistikken for 1936/37, nesten femti år etter at sløyd ble innført som obligatorisk fag, viste at nesten 3800 skoler manglet sløydlokaler (Grunnskolerådet, 1983, s. 16-17).

\section{Folkeskolelovene fra 1936 og Normalplanen for byfolkeskolen 1939 (N39)}

Lovene som innførte enhetsskolen inneholder heller ikke spesifikke krav til spesialrom. Men under $\S 10$ finner vi at rommene skal være tilstrekkelig store, passe til formålet og være forsynt med nødvendig innbo og de læremidler som trengs etter de minimumskrav som departementet stiller (Loven om folkeskolen i kjøpstædene, 1936, s. 14). Videre at «Skolen skal holde elevene med lesebøker, skrive- og tegnesaker samt materiale til sløyd- håndarbeids og husstellsundervisning» (Loven om folkeskolen i kjøpstædene, 1936, s. 14). Lignende finner vi under samme paragraf i Loven om folkeskolen på landet.

I N39 er fagplanene for de tre fagene delt opp i mål, minstekrav, rettleiing, og arbeidsplan for klassene. Tegning har 2 mål hvorav det ene er «å fremme og styrke anlegg for formende arbeid hos barn ved å gi opplæring i bruk av forskjellige formålstjenlig materiale» (KUD, 1939, s. 168). Under Forestillingstegning finner vi at «[...] elevene bruker de tekniske hjelpemidler (blyant, farge, tusj, kull, farget papir, linoleum) på en reinslig og formålstjenlig måte» (s. 169). I rettledningen under Teknikk beordres med påbud at «Læreren må gi rettleiing i bruk av formålstjenlig materiale og redskaper, som blyant, tørr og våt farge, farget papir, enkle trykkteknikker, redispenn o.I.» (s. 170). På samme side nevnes tekniske hjelpemidler: «Vannfarger, dekkende vannfarger, fargestifter. Klisterfarge. (Anilinfarge - som er oppIøselig i vann - utrørt i klister som er laget i arabin, potetmel dekstrin e.l.).» Avsnittet Teknikk avsluttes med Trykkteknikk: «Å skjære klisjéer i linoleum, potet, gummi eller kartong og trykke med sverte. Av verktøy kan en nevne Tif nr. 1, 3 og 5. Til skrift og tegning kan en bruke redispenn i forskjellig tykkelse fra $1 / 2 \mathrm{~mm} »(K U D, 1939$, s. 170).

Bestemte tegneoppgaver på ulike trinn beordres med forbudet må ikke. Kopiering og innøving av tegneteknikker som for eksempel perspektivtegning omfattes av forbudet. Dette begrunnes i at slike tegninger har liten betydning for barnets utvikling da de ikke er «[...] formet av barnet selv ut fra et indre syn» (KUD, 1939, s. 171). Under Arbeidsplan for klassene (s. 171-175) nevnes ingen tekniske hjelpe- 
midler under 1. og 3. klasse. Samtidig beordres det med presens at elevene tegner så mye som mulig med opplæringa ellers (s. 171). Tegning foregår altså ikke i et spesialrom. Under 4. og 6. klasse nevnes klisterfarger. Under 6. og 7. klasse hvor avtegning (bunden tegning) er en del av planen, finnes det ingen beordringer av verktøy og utstyr, men det henvises i en fotnote til Foreningen Brukskunst som etter oppfordring har «[...] nedsatt et utvalg av skolekyndige og brukskunstnere som skal samarbeide om valg av høvelige ting [...]» (s. 174) for avtegning. Det er i det hele tatt lite i arbeidsplanen som beordrer bestemte typer materialer, verkt $\varnothing y$ eller utstyr i Tegning. Det beordres heller ikke hvordan undervisningsrommet skal, bør eller kan være innredet. Det er nærliggende å tenke at når kopiering og tegneteknikker frarådes, vil et spesialrom tilrettelagt for ulike teknikker ikke bare være unødvendig, men kunne avlede barnet fra å forme selv ut fra et indre syn.

Handarbeid for gutter (sløyd) har som Mål at elevene skal medvirke i planleggingen og utføringen av et arbeid, forstand, vilje, dømmekraft skal trenes, sans for god form og farge skal utvikles og elevene skal vennes til pent og nøyaktig arbeid. Videre skal sløydarbeidet hjelpe til «[...] å skape glade, driftige og handledyktige mennesker» (KUD, 1939, s. 182). Målet er overordnet og beordrer ikke læring av spesifikke håndverksteknikker. Under Minstekravene er faget delt opp i Pappsløyd og Tresløyd. Under pappsløyd beordres at «eleven skal kunne den redskapen som er nødvendig i pappsløydarbeidet» (s. 182). Under tresløyd på samme side skal elevene kunne «bruke riktig den alminnelige sløydredskap som skolene er utstyrt med». Det er altså opp til skolen å tolke hvilke verktøy som er nødvendige, alminnelige og som derfor skal finnes tilgjengelig. Noe kan utledes fra ulike teknikker som elevene skal kunne; for eksempel å sette sammen med spiker, skruer og innfelling, røre ut oljefarger og male, rense og stelle malekost og pensler (s. 182). Samtidig peker planen på i presens at oppøving av tekniske ferdigheter tones ned om det går på bekostning av formingsarbeidet «[...] som er det mest utviklende for elevene» (s. 184). Her skal altså oppøving av teknikker kun tones ned og ikke forbys som i faget Tegning.

I rettledningen beskrives undervisningen gjennom 13 punkter. Punkt 13 beordrer at det som regel «[...] ikke bør være flere enn 15 elever på hvert sløydparti, eller aldri mer enn 30 elever med 2 lærere» (KUD 1939, s. 185). Dette begrunnes ikke, men sløydfaget har da vært en del av skolen i 50 år, så det er rimelig å tenke at beordringen gjøres ut fra fagdidaktiske tradisjoner og erfaringer. Jeg undres over hva erfaringen er og hvorfor begrensningen ikke beordres med må eller kan ikke.

I planen for Handarbeid for jenter (tekstil) er målet «å lære dem ymse slag haandarbeid: søm, strikking, hekling, i de øverste klasser også klipping og behandling og bruk av symaskinen» (KUD, 1939, s. 188). Det er rimelig å tenke at det å lære å bruke symaskin vil kreve både plass og spesiell innredning av undervisningsrommet. Under minstekrav finner vi en rekke teknikker; hånd- og maskinsøm, håndstopping, lapping, hekling, strikking og (enkel) norsk prydsøm. Under rettleiing finner vi, som i håndarbeid for gutter, at «Det bør i regelen ikke være mer enn 15 elever på hvert handarbeidsparti» (s. 189). Begrensningen i elevtall begrunnes heller ikke her. Fra planen kan det utledes hva som trengs av materialer, verktøy og utstyr, men det finnes ingen beordringer som direkte peker på utforming av spesialrom for håndarbeid for jenter.

I 1947 ga KUD ut en tolkning av folkeskolelovene fra 1936. Her presiseres det at «Når det gjelder innredning av rum for husstell, håndarbeide, og gymnastikk bør skolestyrerne på forhånd rådføre seg med statens konsulenter for disse fag» (KUD, 1947a, s. 35). Dette er konsulenter som KUD knyttet til seg i perioden 1946-1976. Antallet fagkonsulenter $\varnothing$ kte til hele 17 fram til 1976 når stillingene overføres til det nyopprettede Rådet for videregående opplæring (Kolsrud, 2008, s. 228). Med andre ord, skolene henvises i disse årene til hjelp fra sentralt ansatte fagkonsulenter med hensyn til innredning av spesialrom for sløyd og tekstil.

\section{Normalplanen for landsfolkeskulen 1947 (N47) og Typeplaner for skolehus i bygdene}

Kirke- og undervisningsdepartement (KUD) oppnevnte en typeplankomite i 1939 hvor oppdraget var å beskrive og stille krav til ulike typer skolehus. Noe forsinket på grunn av krigen, sendte KUD ut Typeplaner for skolehus i bygdene til landets skoledirektører og skolestyrer i 1946. Samtidig, i løpet av 19451947, ansatte KUD en fagkonsulent i sløyd for gutter, en fagkonsulent i håndarbeid for jenter og en tegnekonsulent (Kolsrud, 2008, s. 228). Vi kan tenke oss at konsulentene var sterkt involverte i utformingen av typeplanene. 
Typeplanene ser ut til å være gitt ut i sammenheng med Normalplanen for landsfolkeskulen som kom i 1947 (N47). Etter målene for fagene Handarbeid for gutter og Handarbeid for jenter stilles det her minstekrav på lignende måte som i N39; guttene skal kunne «bruka rett den reiskapen som er turvande i pappsløydarbeide» (KUD, 1947b, s. 183) og skal kunne «bruka rett den vanlege sløydredskapen som skulane har» (s. 183) Minstekravene spesifiseres til blant annet å kunne ta riktige mål og sammenføye med spiker, skruer og innfelling (s. 183). Til jentene stilles det lignende krav som at de skal kunne stopping, lapping og bøting. Å merke seg er at det i N47 beordres at jentene kun må kunne håndsøm (s. 189), ikke maskins $\varnothing \mathrm{m}$ slik N39 beordrer. Spesifiseringene i minstekravene i de to håndarbeidsfagene gjør at det kan utledes hva som trengs av verktøy og utstyr.

I faget Tegning skilles det mellom Førestellingsteikning, Avteikning (bunden teikning) og Fagteikning (teikning i samband med andre skulefag) (s. 170). Under Minstekrav pekes det på at det ikke kan stilles minstekrav i forestillingstegning «[...] da det må væra fridom i opplæring av dette slaget» (s. 169). Som i N39 understrekes det at å kopiere eller å lære perspektivregler ikke har noen verdi da slike tegninger ikke er forma ut fra barnets indre syn (s. 172). Tekniske hjelpemidler som nevnes er blyant, farge, tusj, kull, farga papir og linoleum (s. 170) samt vannfarger, klisterfarger, potet-, gummi-, kartongog linoleumstrykk (s. 171-172). Angående læremidler i bunden tegning vises det som i N39 til Foreningen Brukskunst hvor man kan bestille passende ting til avtegning. Fagteikning, en blanding av forestillingstegning og avtegning $i$ andre fag, begrunnes med at fagtegningen gir en klarere og mer forståelig framstilling enn bare med ord (s. 176). På samme side anbefales det at fagtegning bør være skissepreget for at den ikke skal stjele tid fra faget - fagtegning synes derfor ikke å være utstyrskrevende.

I Typeplaner for skolehus i bygdene, under kapittelet Administrative direktiver og rettleiing for bygging av skolehus, stilles det krav til utforming av både Sløydrom og Håndarbeidsrom (KUD, 1946, s. 12-14 og s. 16-17). Her pekes det for eksempel på nødvendigheten av å ta hensyn til den støy som følger med sløydundervisningen. Det anbefales å legge rommet et stykke unna $\varnothing v$ rige klasserom, alternativt å lydisolere rommet godt. Det beordres med forbud at sløydrommets golv ikke må «[...] ligge lavere enn $80 \mathrm{~cm}$ under tilst $\varnothing$ tende terreng» (s. 12) da dette kan føre til fuktproblemer og for lite dagslys. Under Størrelse pekes det på at dette avhenger av antall benker og hvor mange elever som skal undervises samtidig. «I udelt og 2-delt skole må en regne med 10 benker, ved 6-delt og 7-delt 16, men det er bra om det er plass til 18 ved disse større skoler» (KUD, 1946, s. 13).

Som alminnelig regel kan en si at sløydrommets størrelse bør beregnes rommelig. Særlig gjelder dette ved de 5-, 6-, 7- delte skoler hvor en bør regne med høve til også å gi undervisning i metallsløyd, eller at det kan bli anskaffet arbeidsmaskiner som båndsag dreiebenk o.l. Ikke minst er dette tilfelle hvor sløydrommet også vil bli brukt av framhaldsskolen. (KUD, 1946, s. 13)

På samme side står det at sløydrommets areal ikke må være mindre enn $4 \mathrm{~m}^{2}$ pr. benk. I de vanlige undervisningsrommene med målene 48 og $50 \mathrm{~m}^{2}$ angis at man bør regne med plass til 30 elever (s. 12). Det betyr at KUD beordrer med påbud et areal pr. elev i sløydrommet som er nesten 2,5 ganger så stort pr. elev som i de vanlige undervisningsrommene. Arealkravet begrunnes ikke. Videre i typeplanene, under overskriften Inventar, utstyr og belysning, beskrives innredning og plassering av ulikt utstyr som benker og verktøyskap. Dagslys $b \varnothing r$ være særlig godt, «Netto lysflate minst $1 / 4$ av golvflaten, men helst mer» (KUD, 146, s. 13). Det pekes på at siden sløydrommet ikke er egnet til å arbeide med maling og annen overflatebehandling, $b \varnothing r$ det i direkte tilknytning være et eget rom til dette. Her $b \varnothing r$ det være en glassvegg mot sløydrommet (slik at lærer kan holde oppsikt). I rommet for overflatebehandling må det være særlig god belysning og hensiktsmessig plass til et stort arbeidsbord samt $50 \mathrm{~cm}$ dype skap og reoler for lagring av elevarbeider og nødvendig materiell og utstyr (KUD, 1946, s. 13). I tilknytting til sløydrommet $b \varnothing r$ det være et eget materialrom som kan ha kunstig belysning (helst et lite vindu for lufting), med plass til 50-60 cm dype knekter. Det er ønskelig at materialrommet er minst 5 meter langt med plass for lagring av 15 fots materialer og en sagbukk hvor materialene kan kappes. Dersom det ikke er mulig å avse et eget materialrom får knektene plasseres i sløydrommet, men da må dette rommet gjøres tilsvarende større (KUD, 1946, s. 13-14). Det bør også være et lite rom hvor elevarbeidene kan lagres, «[...] så sløydrommet ikke belemres med disse» (s. 14). 
Under håndarbeidsrom (tekstilrom) (s. 16-17) beordres det med bør et eget rom for dette så sant $\varnothing$ konomien tillater det. Dette begrunnes med effektivitet og muligheter for å la undervisningen gå inn som et daglig ledd i undervisningen. Håndarbeidsrommet

[...] bør ikke være mindre enn vanlige klasserom. Rikelig med skapplass letter arbeidet og gjør det mulig å holde elevene til en gjennomført orden så alle ting får sin hensiktsmessige plass. Et lite materialrom ved siden av er derfor ønskelig. Har en 2 arbeidsrom, kan de ha felles materialrom. (KUD, 1946, s. 16)

Belysningen, både den naturlige og den elektriske, må være særlig god. Rikelig skapplass beordres ikke med påbud, men begrunnes med at det letter arbeidet og muliggjør orden. «Et lite materialrom ved siden av er derfor ønskelig» (KUD, 1946, s. 16) Det er videre ønskelig med ikke alt for store elevgrupper; anslagsvis bordplass for 15-16 elever. De eldste $b \varnothing r$ ha hvert sitt bord. Dobbeltbord $b \varnothing r$ ha en st $\varnothing r r e l s e$ på minst $75 \times 135 \mathrm{~cm}$, høyde ca. $75 \mathrm{~cm}$. Under bordplata bør det være en hylle eller to skuffer. En stol til hver elev. Til hver plass må det være en fotskammel til mindre elever. Lærerinnen har ved den ene kortveggen sin plass ved et stort demonstrasjons- og målebord. Langs begge kortvegger skal det være så store tavler som mulig. Skap for materialer og saker under arbeid bør fortrinnsvis plasseres ved indre langvegg. Dette begrunnes med at lyset fra vinduene da faller rett inn i dem. Målene på skapene bør være omtrent $55 \times 160 \times 210 \mathrm{~cm}$. Det bør være garderobestang i halvparten av skapene og det må også være skap for ferdige arbeider. Det $b \varnothing r$ være skap for oppbevaring av symaskiner, bøker og mønstertegninger i nærheten av lærerinnens plass; «[...] En regner med 1 symaskin for 3 elever» (s. 17). Videre på samme side at det bør være en eller flere stikkontakter til bruk for elektriske symaskiner. På høvelig plass monteres et strykebrett, her bør det være en egen arbeidslampe og stikkontakt. Dersom en ikke har anledningen til å innrede et håndarbeidsrom, bør et av klasserommene innredes med sikte på håndarbeidsundervisning; her må det være bord og stoler, og ikke pulter, samt de nødvendige stikkontakter.

KUDs Typeplaner for skolehus $i$ bygdene avsluttes med korte beskrivelser og plantegninger av seks ulike typer skolehus, fra små til store (KUD, 1946, s. 30-40). Her er også inventar som sløydbenker, arbeidsbenker og skap tegnet inn. Figuren under (figur 1) viser beskrivelsen av de ulike typene skolehus (s. 20) samt plantegninger som viser skolehus type 1, 2a og 2b (s. 21). Typeplanener for skolehus i bygdene inneholder også informasjon om lover og forskrifter, behandling av byggesaker, administrative direktiver og rettledninger samt Byggebeskrivelse til retledning av vedlikehald (s. 28) og endelig Søknadsskjema om rikstilskot til bygging av skolehus (s. 6-7).

Vi ser at staten i Typeplanene for skolehus på bygdene beordrer hvordan spesialrommene skal og bør være utformet, at flere av beordringene inneholder tallfestede krav og er formet som påbud og forbud. Jeg oppfatter at beordringene er basert på fagdidaktisk tradisjon eller erfaring da de i liten grad begrunnes. En kan tenke seg at kommunene la stor vekt på å følge typehusbeskrivelsene for å få det nødvendige tilskuddet fra staten. En kan av samme grunn tenke seg at det ble tilstrebet å ikke bare fylle beordringene som er gitt som påbud og forbud, men også som anbefalinger i de modale beordringene bør, kan, ønskelig og helst. 


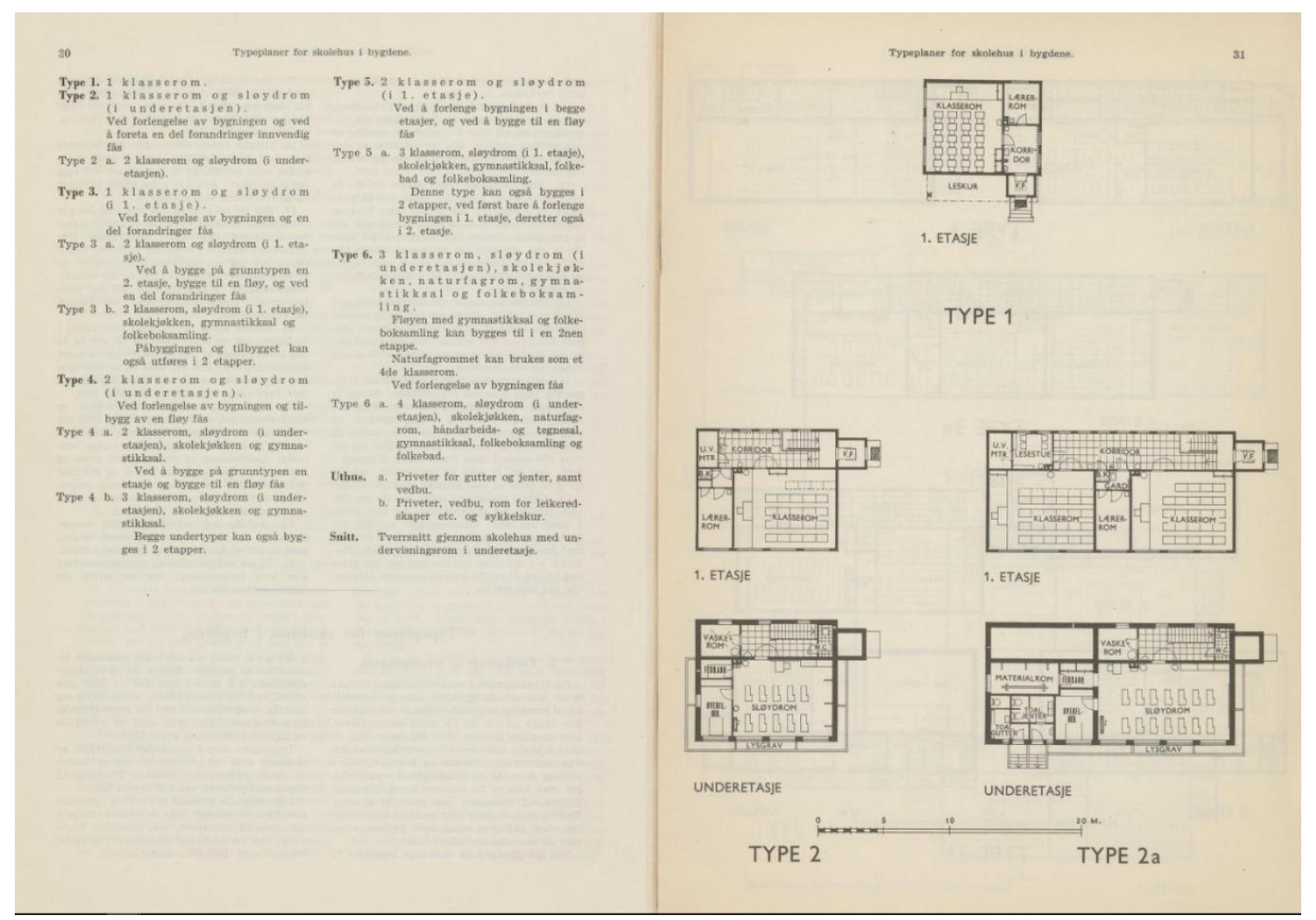

FIGUR 1. Fra Typeplaner for skolehus i bygdene (KUD, 1946, s. 20-21).

\section{FAGET FORMING}

Med innføring av 9-årig grunnskole og Læreplan for forsøk med 9-årig skole i 1960 (F60) ble fagene Tegning, Håndarbeid for gutter og Håndarbeid for jenter slått sammen til ett fag; Forming (KUD, 1960). Denne sammenslåingen bygde på ideologiske strømninger i tiden, men også på økonomiske prioriteringer. Dette åpnet opp for nye tanker knyttet til spesialrom.

\section{NTH-kurs i skolebygging}

I 1958 arrangerte Arkitektavdelingen ved Norges Tekniske Høgskole (NTH) et større kurs i skolebygging. Noen av de publiserte innleggene (Dalaker \& Bastiansen, 1959) inneholder refleksjoner rundt krav til spesialrom for det nye faget Forming. NTH hadde høy status, og det er det trolig at de i alt 36 foredragsholderne, hvorav en fra Tyskland og en fra England, representerer ideene til noen av de viktigste akt $\varnothing r-$ ene innenfor skole- og arkitektturfeltet. Det er rimelig å tenke at kurset må ha gitt viktige impulser til utformingen av spesialrom i årene som følger. Under kommer de viktigste ideene som ble presentert på NTH-kurset i 1958 med hensyn til spesialrom for det nye faget Forming.

En av foreleserne, daværende rektor Torleiv Hellkås ved Statens sløyd-og teiknelærarskole (SSTL) på Notodden, går i framlegget Rom for sløyd-og tegneundervisning (Hellkås, 1959, s. 93-98) først gjennom innredning av spesialrom for tre- og metallsløyd, tegnesal og keramikkrom. Han peker deretter på at fagene man nå skal samle til et fag vil skifte karakter, og at det ikke er lett å si hvordan eller hvor store forandringene vil bli (s. 96). Videre sier han at det etter hans oppfatning ikke er mulig «[...] å gi endelige retningslinjer for innredning av spesialrom for formingsfagene» (s. 98). Han hevder også at man kan spare inn på spesialrommene ved i langt større grad å bruke klasserommene til en rekke av formingsaktivitetene. Han skisserer deretter to retningslinjer for arkitektene; fleksible romløsninger ved å sette opp flyttbare lettvegger og samling av formingsaktivitetene omkring et sentralt studierom for å tilrettelegge for integrering innen formingsfagene samt integrering utover faggrensene (s. 98). Han mener at arkitekter og skolefolk sammen, ikke bare har gode muligheter for å skape gode 
formingsrom, men også til å «[...] lede opplæringen inn i en bestemt retning. Og nettopp arkitektene skulle ha store sjanser for å lykkes i et slikt arbeid, fordi estetisk undervisning, estetisk oppseding, ligger så nær opp til arkitektens egen utdanning og til hele hans virkemåte» (s. 98). Kort sagt så var rektoren på den høyeste lærerutdanningsinstitusjonen i Norge innenfor sløyd og tegning usikker på hva sammenslåingen til Forming ville bety og inviterte arkitektene til et samarbeid med faglærere om ikke bare å finne ut av hvordan spesialrommene skulle se ut, men hva faget skulle være.

I avsnittet Rom for kombinert aktivitet i skolen (Arnljot, 1959, s. 108-112) presenterer øvingslærer Ivar Arnljot ideer til ulike typer aktivitetsrom. Da han sannsynligvis er invitert i kraft av sin posisjon som $\varnothing$ vingslærer, er det rimelig å tenke at ideene han presenterer springer ut fra, eller samsvarer med, ideene til SSTL (Statens Sløyd og Tegnelærerskole), utdanningsinstitusjonen han jobbet ved. At han jobbet i praksisfeltet, tilfører ideene tyngde. Arnljot hevder at formålet med de praktiske fagene i 9-årig skole er å gi elevene muligheter til personlig utfolding gjennom skapende arbeid, de skal virke motiverende og de skal endelig virke orienterende mot framtidige yrkesvalg (s. 108). Han peker på at den fådelte barneskolen aldri vil kunne by sine elever et aktivitetsrom da de er såpass utstyrskrevende, og at det her heller må tas sikte på å legge de praktiske aktivitetene til de ordinære undervisningsrommene (s. 109). Deretter følger tre plantegninger som viser ulike måter man kan organisere et vanlig undervisningsrom som aktivitetsrom. Et bilde viser hvordan en sløydbenk «[...] ved hjelp av en plate på et фyeblikk kan omdannes til et godt arbeidsbord for vanlige klasseromsformål» (s. 111). Problematikk rundt armslag, støy, skadelig pussest $\varnothing \vee$ og renhold løfter han ikke frem.

De publiserte innleggene fra NTH-kurset i skolebygging tyder på at det fra sløydfaglig hold er tvil og ulike ideer om hva det nye faget Forming skal være, samtidig som det uttrykkes at de praktiske fagene først og fremst er metodefag. Forming foreslås integrert i andre fag, og dermed kan også kostnadene med spesialrom begrenses eller fjernes. Dette støttes av rektor Tønnes Sirevåg, leder i det daværende Fors $\varnothing$ ksrådet for skoleverket, seinere rektor ved Katedralskolen og også sentral i Kirke- og Undervisningsdepartementet under innføringen av 9-årig skole. På NTH-kurset la han frem Proposisjon om lov om folkeskolen og spørsmål om skoleutbygging og romkrav (Sirevåg, 1959, s. 55-61). Her hevder han blant annet: «Dei praktiske faga i den pliktige ålmennskolen skal fyrst og fremst være pedagogiske instrument. Eit viktig føremål med desse faga er å skape trivnad, interesse og gode arbeidsvanar» (Sirevåg, 1959, s. 58). Ut fra at disse fagene først og fremst er metodefag konkluderer han med at fagene heller ikke har behov for spesialrom. Man kan bruke de vanlige undervisningsrommene til hobbyarbeider hvor kravet til verktøy og utstyr ikke vil medføre så høye kostnader. «Hobbyverktyet vil og hindre at høvling og sying får breie seg på kostnad av andre verdifulle aktiviteter» (s. 59). Endelig mener Sirevåg at nedleggingen av spesialrommene og tilrettelegging for hobbyaktiviteter i de ordinære undervisningsrommene er en betingelse for å «[...] få ei føremålstenleg integrering av teoretiske og praktiske fag» (Sirevåg, 1959, s. 59). Som leder i Fors øksrådet for skoleverket er det rimelig å tenke at hans ideer om de praktiske fagene ikke bare har hatt tyngde på NTH-kurset men også har innvirket på F60 som han var ansvarlig for. (Tønnes Sirevåg ble 31 år seinere (1989) ridder av 1. klasse av St. Olavs Orden for sin innsats for norsk skole.)

På NTH-kurset pekes det også fra arkitekthold på utfordringen med dyre spesialrom. I innlegget Skoler og økonomi (Selvåg, 1959, s. 149-157), peker sivilingeniør Olav Selvåg på at spesialrommene både er de dyreste rommene og at de har en dårlig utnyttelsesgrad. (Selvåg hadde 10 år tidligere satt opp «Ekeberghuset» for å bevise at det er mulig å bygge både raskere og billigere dersom man reduserte kravene i byggeforskriftene). Han ser en løsning i å plassere flere sløydbenker på et mindre areal for å spare på kostnadene. Selvåg viser til en dansk sløydsal på $64 \mathrm{~m}^{2}$ med 30 spesielt slanke sløydbenker, i motsetning til en norsk sløydsal på $72 \mathrm{~m}^{2}$ hvor det kun er plass til 15 benker av norsk type (Selvåg, 1959, s. 151). Han har i framlegget ingen fagdidaktiske refleksjoner over elevantallene eller hva som trengs av materialer, verktøy og utstyr.

\section{Læreplan for forsøk med 9-årig skole - Forsøksplanen 1960 (F60)}

Arbeidet med Fors $\varnothing$ ksplanen ferdigstilles i 1960 med rektor Tønnes Sirvåg som leder. Planen for det nye faget Forming har et tydelig fokus på elevens utvikling. Hovedmålet er «å utvikle og kultivere skapende krefter og estetisk følsomhet» (KUD, 1960, s. 288). Under overskriften 3. Evaluering understrekes det at 
hovedvekten iformingsarbeidet «[...] blir lagt på den personlige utviklingen hos eleven. Vanlig karaktergiing høver derfor ikke i forming» (s. 291). Under overskriften 6. Materialer og arbeidsmåter finner vi at "Manuell ferdighet og teknisk dyktighet er viktig for formingsundervisningen i den grad de kan tjene hovedmålet, å utvikle og kultivere skapende krefter og estetisk følsomhet» (s. 292). Deretter nevnes eksempler på materialer som kan anvendes for å nå dette målet; plastelina, pappmasje, horn, never, bark, linoleum, kongler og glassbiter. Det understrekes at disse materialene må likestilles med de tradisjonelle materialene $t \varnothing y$, tre og metall. «Det som har betydning fra formingssynspunkt er ikke hvilke materialer barna arbeider med og hvilke tekniske ferdigheter de tilegner seg. Det viktigste er den utvikling som barna gjennomgår» (KUD, 1960, s. 292).

Av dette følger at det ikke kan oppstilles egentlige minstekrav $i$ kunnskaper og ferdigheter når det gjelder formingsundervisningen. De arbeidsmåter som barnet tilegner seg og den ferdighet det oppnår i verktøybehandling, vil nok være en forutsetning for og en følge av barnets arbeid med materialene. Derimot vil de tekniske ferdigheter ikke være selvstendige mål for formingsundervisningen, og enda mindre vil de utgjøre fikserte minstekrav. (KUD, 1960, s. 292)

Når det i læreplanen beordres at håndverksferdigheter ikke skal være selvstendige mål, og at det heller ikke skal stilles minstekrav i kunnskaper og ferdigheter, er utforming av spesialrom for håndverksbaserte teknikker ikke nødvendig. Planen inneholder imidlertid et eget kapittel Rom og utstyr (KUD, 1960, s. 328-368). Under overskriften A. Rom anbefales det modalt at en del av undervisningen kan foregå i klasserom som er store nok og som har det nødvendige utstyret og videre med påbud at

Rom som innredes til kombinerte klasse- og aktivitetsrom eller egne formingsrom, skal være arbeidsrom hvor det er mulig å drive en rekke sysler samtidig, og hvor det ved innredningen er tatt omsyn til at læreren har best mulig oversikt over alle gruppe-arbeidsplassene. Dette krever god plass, lett og flyttbart utstyr, slik at rommet kan ommøbleres etter behov. Det er også viktig at rommet er formålstjenlig delt mellom de ulike aktivitetsområder. (KUD, 1960, s. 328)

Fors $\varnothing \mathrm{ksplanen}(\mathrm{F} 60)$ konkretiserer deretter, ved hjelp av tekst og plantegninger, en rekke forslag til romIøsninger ut fra ulike trinn og skolestørrelser. Rommene er tenkt slik at de kan brukes flere fag som for eksempel Heimkunnskap, Forming og Kroppsøving. I figuren under (figur 2.) vises en «Skisse av klasseog aktivitetsrom for fådelte skoler med plass til forming, og heimkunnskap i barneskolen. Rommet vil gi plass til kroppsøving når arbeidsbenkene flyttes til side» (KUD, 1960, s. 329). Man kan stille spørsmål ved hvor realistisk dette er. Ut fra skissen ser det i alle fall ikke ut til å være store plassen å boltre seg på etter at arbeidsbenkene er satt til side.

Deretter i planen, under B. Utstyr, listes det opp over hele 29 sider Verktøy og utstyr for $\varnothing$ vrig for aktivitetsrom på ulike trinn og skolestørrelser (KUD, 1960, s. 339-368). Her finnes det også en liste med et utvalg av håndbøker og tidsskrifter. To sider av disse listene vises i figuren under (figur 3). Listene inneholder ikke beordringer og må oppfattes som anbefalinger. Likevel er det nærliggende å anta at listene kan brukes av faglærere som argument for innkjøp av materiell til faget. Det store omfanget samsvarer med kravet i planen om at elevene i faget Forming skal møte et bredt materialomfang. Man kan undres over om det store omfanget i denne lista motiverte og førte til innkjøp eller om den vekket motstand fordi den ble oppfattet som urealistisk og detaljstyrende. 


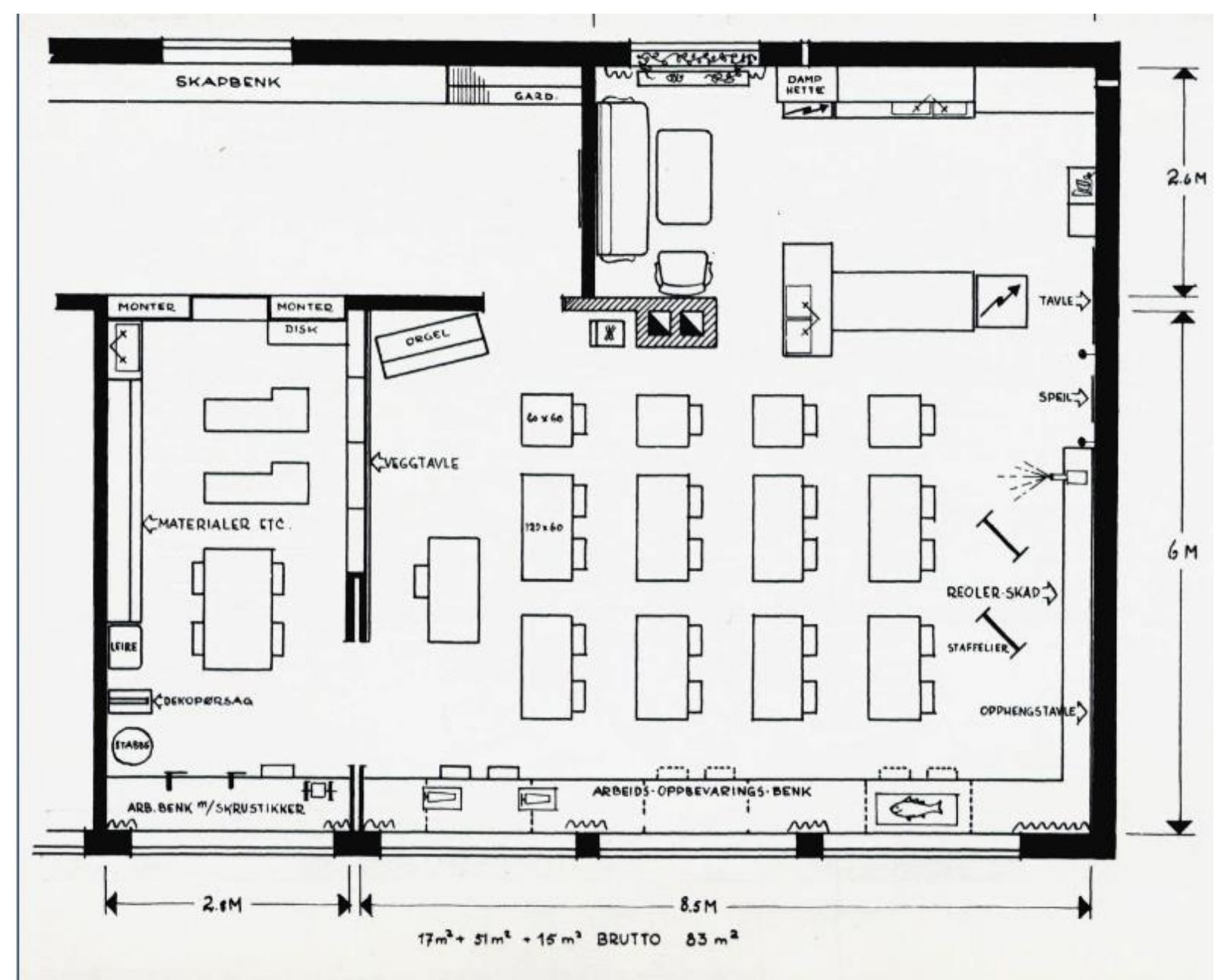

FIGUR 2. Fra Læreplan for forsøk med 9-årig skole (F60) (KUD, 1960, s. 329). 


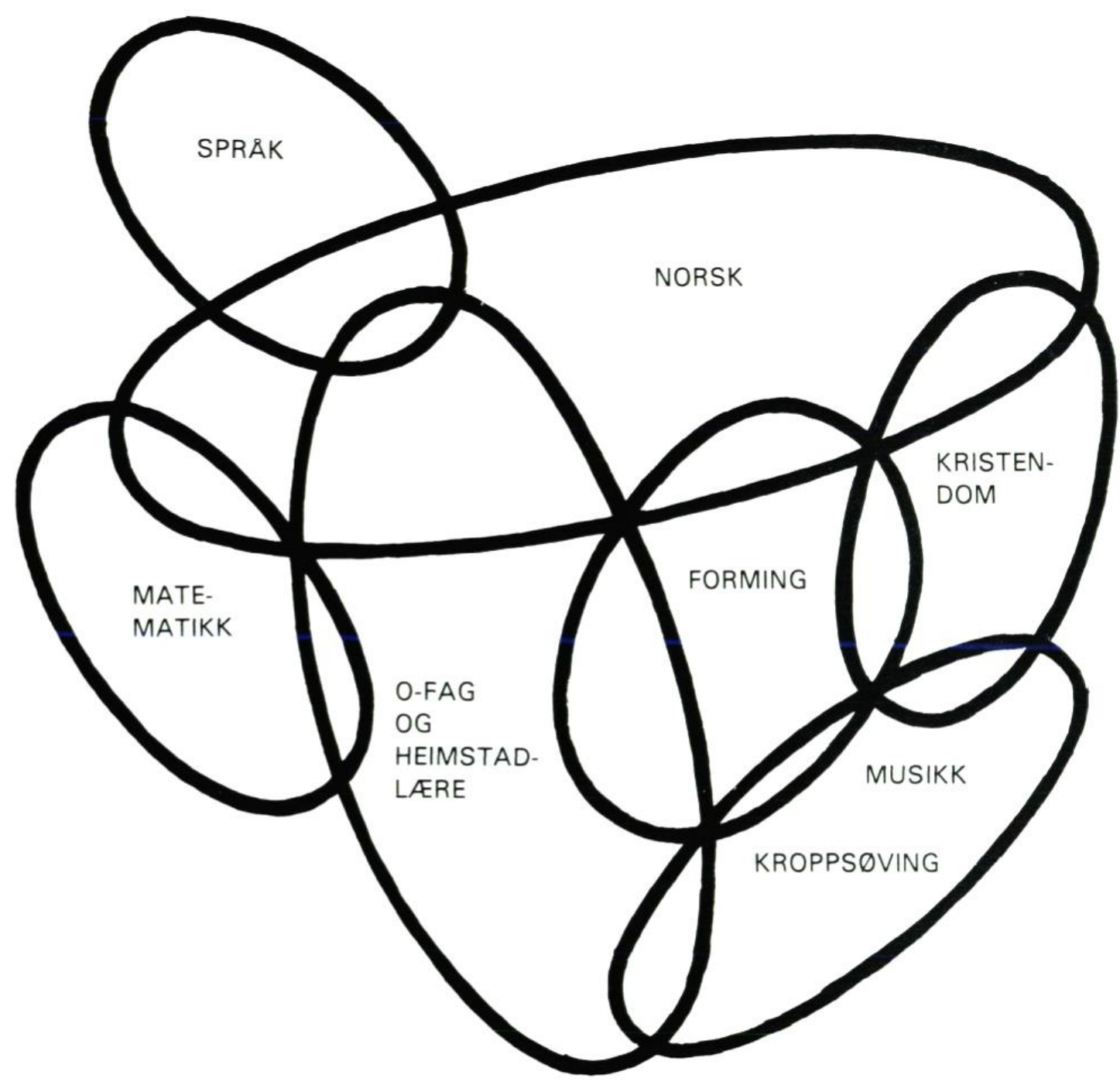

FIGUR 4. Grunnskolerådets framstilling av hvordan ulike fag overlapper i grunnskolen (Grunnskolerådet, 1972, s. 5-6).

Ut fra ideen om integrering peker Grunnskolerådet på fordelen med en åpen planløsning i nærhet til klasserom, helst uten vegger. Eventuell inndeling med vegger og skjermer begrunnes med plass for plassering av skap og utstyr samt skjerming for smuss, st $\varnothing \vee$ og st $\varnothing y$. Åpen løsning begrunnes med bevegelsesfrihet, integrering av de ulike fagdisiplinene og de ulike fagene (Grunnskolerådet, 1972, s. 8 og s. 30). En åpen løsning støtter også at elevene skal ha fri tilgang til, og selv velge ulike materialer (s. 30). Hvordan det skal holdes orden på materialene nevnes ikke. Grunnskolerådet gjør et poeng av at undervisningsarealet kan $\varnothing$ kes betydelig når trafikkarealene sløyfes (s. 16). At trafikk i undervisningsarealene kan forstyrre, løftes ikke frem.

Synet på spesialrom er at man må bruke og tilpasse det man har, og selv ved nybygg «[...] vil mange forhold tilsi at en bestemt standardløsning ikke lenger kan fremheves som den riktigste» (Grunnskolerådet, 1972, s. 3). Grunnskolerådet fremhever at det ikke er behov for spesialrom til verkstedformål på de laveste klassetrinnene, 1.-3. klassetrinn (s. 16). «[...] formingsaktivitetene på dette trinnet foregår naturligst i klasserommet eller klasseområdet». Hvorfor klassetrinn 1-3 ikke har behov for spesialrom begrunnes ikke utover at det er naturlig. Dersom det på de høyere trinnene skal deles inn i spesialiserte rom eller verksteder vil disse, ifølge Grunnskolerådet, være tilbud som elevene oppsøker etter behov (s. 29). Grunnskolerådet skissere tre ulike modeller; rom med allsidig utstyr hvor elevene kan arbeide over et bredere aktivitetsområde, rom med klart særpreg hvor læreren gir oppgaver som høver for rommet, 
samt spesialrom som tilbud ut fra de enkelte elevers arbeidssituasjon (s. 29). Hvordan de ulike tilbudene ut fra behov skal løses organisatorisk nevnes ikke.

Mye tyder på at det er integreringstanken og elevenes frihet til å velge hva de skal arbeide med og lære, som er de bærende ideene for organisering og innredning av arealene. Det skilles mellom grad av tverrfaglighet på barnetrinn og ungdomstrinn hvor «[...] integreringen er sterkest i småskolen, men særlig for tegnepreget forming er integreringen tydelig helt opp i ungdomsskolen» (Grunnskolerådet, 1972 , s. 4). På ungdomstrinnet vil integrering «[...] kunne skje mellom de tre sektorene innen selve formingsfaget: tegning, tekstilforming og sløyd» (s. 20).

På side 26 i informasjonsheftet presenteres en skisse som viser hvordan Grunnskolerådet tenker seg en ideell atskilt formingsavdeling på en ungdomsskole med fire til seks paralleller slik det vises i figuren under (figur 5). Her er det organisert med ulike avdelinger ut fra tradisjonelle materialer og teknikker. Det er også tegnet inn et auditorium for 60 elever blant annet for audiovisuelle presentasjoner.

Grunnskolerådet hevder at «Mønsterplanens undervisningsforslag er så elastiske at de uten vansker kan tilpasses bygg med svært ulike romløsninger» (Grunnskolerådet, 1972, s. 30). Ved hjelp av bilder og eksempler på sidene 33-95, gis det råd om tilpassinger og innredning av spesialrom i eldre skolebygg. Temaene er bruk av korridor, desentraliserte småverksteder, keramikkrom, fotorom, oppdeling av arbeidsrom, arbeidsstasjoner, gruppering av arbeidsbord, ulike typer arbeidsbord, maskinelt utstyr, gass (sveising hører ikke hjemme i grunnskolen), st $\varnothing y$, redskaper og verkt $\varnothing y$, materialtilbud, oppbevaringsplass for ting under arbeid, visuelt miljø, samt av-midler.

Interessant er det at veilederen også viser hva som ikke lenger trengs, som for eksempel et bilde av et verktøyskap med tekst som forteller at her er det alt for mange hoggjern og stemjern som ikke er aktuelle lenger (Grunnskolerådet, 1972, s. 72). Neste bilde i heftet viser en åpen verktøytavle hvor rådet er å ikke låse verktøyet bort i et skap. En tilpassing det pekes på for eldre skolebygg er å benytte korridorene til formingsaktiviteter. Et bilde av elever som tegner og maler på gulvet har underteksten: «Selv uten innredning og utstyr kan korridoren anvendes» (s. 37). Hvor hensiktsmessig arbeidsstillingen er eller i hvor stor grad aktiviteten er til hinder for andre problematiseres ikke. Det presiseres heller ikke om bruk av gangarealet skal medregnes i det avsatte arealet for faget Forming eller ikke.

Grunnskolerådets Informasjonshefte nr. 6 Forming, rom og utstyr kom ut i forkant av Mønsterplanen for grunnskolen 1974 (M74). Grunnskolerådet var involvert i planarbeidet ved at de våren 1971 utarbeidet en tilråding om Mønsterplan for grunnskolen. «Det var dette forslag - med enkelte endringer - Kirke og undervisningsdepartementet la fram i Mønsterplan for grunnskolen, midlertidig utgave 1971 (M71)» (KUD, 1974, s. 3). Grunnskolerådet var også involvert i den endelige utgaven da endringer her også var foretatt ut fra Grunnskolerådets innstilling (s. 3). Grunnskolerådet var med andre ord både med på å skrive læreplanen og å tilrå utforming av skolebyggene. 


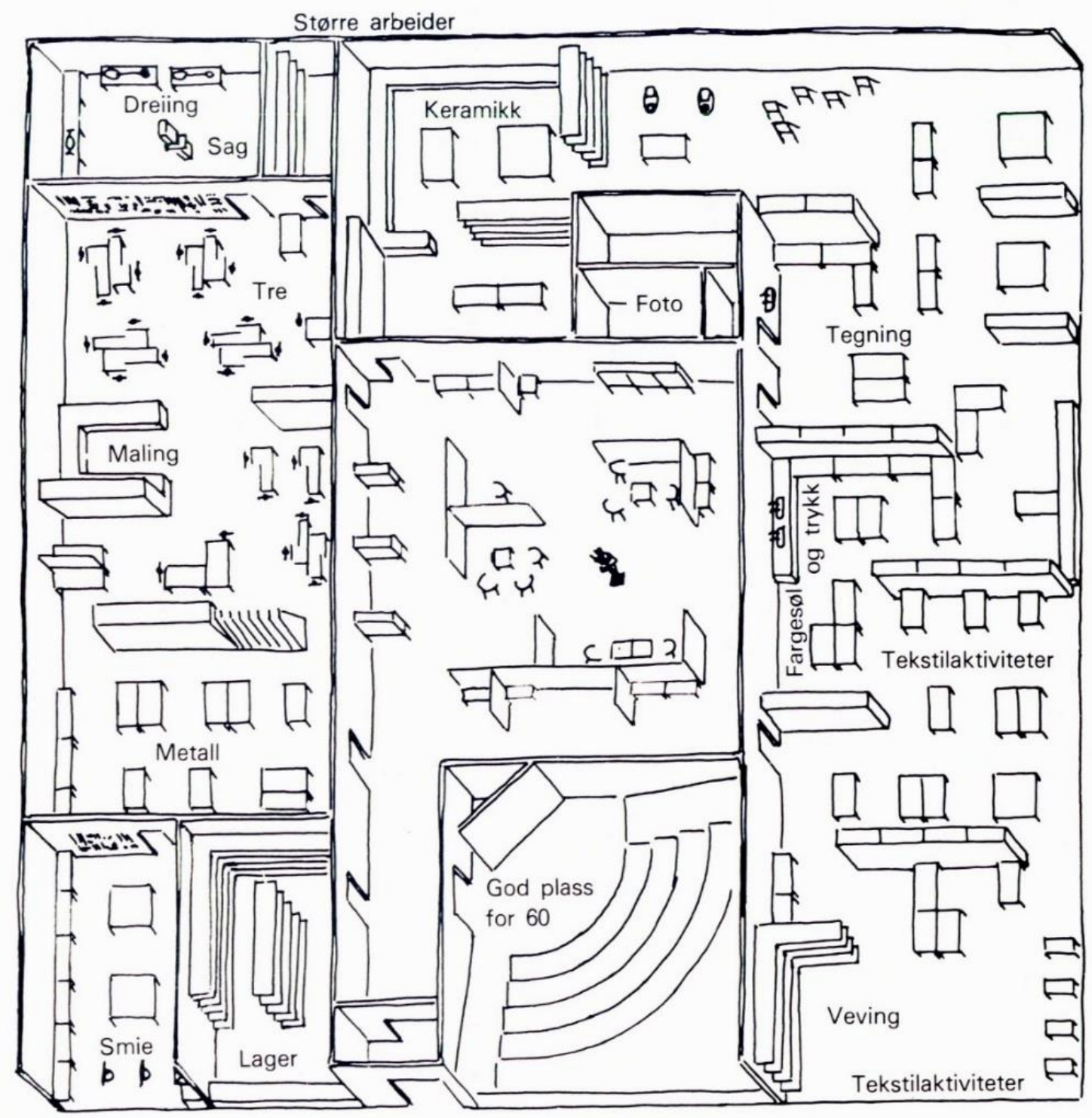

7. - 9. klasse Fire til seks paralleller

Verkstedene er bygd omkring en sentralhall med overlys, f.eks. slik:

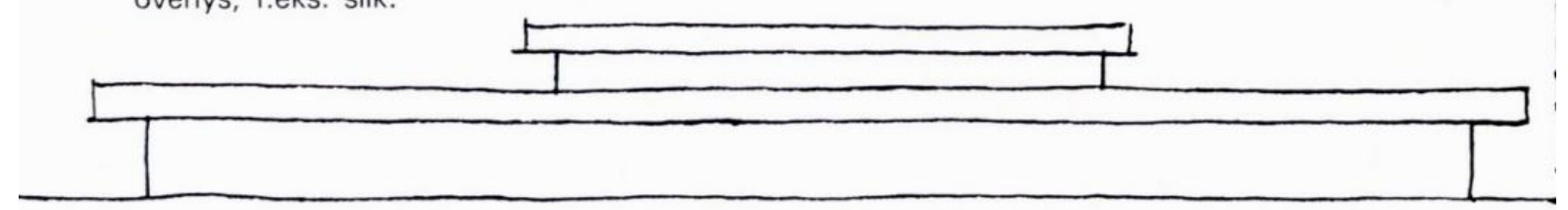

FIGUR 5. Grunnskolerådets romløsning for adskilt formingsavdeling på en ungdomsskole med fire paralleller (Grunnskolerådet, 1972, s. 26).

\section{Mønsterplanen for grunnskolen 1974 (M74)}

I M74 er fagplanen for Forming (KUD, 1974, s. 236-251) delt opp i mål, lærestoff, arbeidsmåter, læremidler, vurdering og veiledende arbeidsplan. Faget har fire overordnede mål som gjelder på alle trinn. 
De følgende delene av planen er fylt med en rekke eksempler, forslag og rettledninger for undervisning. Ett av de fire målene inneholder et ledd med krav om at undervisningen skal ta sikte på å $\varnothing v e$ opp praktiske ferdigheter (s. 236).

Under overskriften Lærestoff beordres det at det er elevens skapende virksomhet som må være det sentrale i undervisningen. "Skolemiljøet $b \varnothing r$ engasjere elevene så sterkt gjennom opplevelser og problemstillinger at det blir et følt behov å få utløsning ved å lage synlig form» (KUD, 1974, s. 236). Hvilke ulike håndverk, verktøy, materialer eller teknikker eleven tenkes å anvende for å lage synlig form detaljeres ikke, men noe kan utledes fra det som står under de enkelte klassetrinn. Her nevnes for eksempel tegning, maling, broderi, applikasjon, sammensetting av plastiske og byggbare materialer, trykkteknikk, maskebinding, veving, nyttesøm, lim, stift, skruer, eller vanlig formingsverktøy og utstyr.

Under arbeidsmåter finner vi at «Det ideelle utgangspunktet for formingsvirksomhet er barnets egne spontane ideér og forslag» (KUD, 1974, s. 237). Det er gjennomgående under overskriften arbeidsmåter at læreren skal tre tilbake og kun motivere og stimulere dersom det er nødvendig å skape et behov for formingsaktivitet i eleven. "Læreren hjelper samtalen framover i retning av løsninger, men uten å gi svar han mener eleven selv kan finne, og uten å vurdere på deres vegne. Derimot gir han tekniske råd og opplysninger der det kan gi eleven bedre formingsmuligheter» (KUD, 1974, s. 238). Med andre ord beordres læreren til ikke å gi noen form for praktisk hjelp i form av håndverk eller tekniske Iøsninger med mindre det er høyest nødvendig. Ideen er at eleven vokser ved å finne løsninger selv. Dette tydelige bruddet med læreplanene for de tidligere håndarbeidsfagene hvor lærling-mesterperspektivet har stått sentralt, åpner for en nedprioritering av spesialrom utformet med henblikk på læring av tradisjonelle håndverk.

Avsnittet Læremidler innledes med en anbefaling i den modale beordringen «Arbeidsrommene i forming bør ha et allsidig og praktisk utstyr for undervisningen [...]» (KUD, 1974, s. 240-241), deretter listes det punktvis opp eksempler på ulike kategorier læremidler.

Punkt 1 omhandler Nødvendig redskap, verktøy og maskiner for de aktiviteter man skal bedrive. Hva som menes med $n \varnothing d v e n d i g$ redskap, verktøy og maskiner detaljeres i planens siste kapittel; Minstekrav til innbo og læremidler i grunnskolen (KUD, 1974, s. 368-375). Her listes det opp en lang rekke minstekrav til skolen generelt og for hvert av de praktisk estetiske fagene spesielt. Beordringene begrunnes i at Lov om grunnskolen av 13. juni $1969 \S 9$ nr. 2 sier at det er departementet som skal fastsette krav til innbo og læremidler (s. 368). Kravene til læremidlene i læreplanen begrunnes med andre ord ut fra loven. Videre står det at departementet forutsetter «[...] at skoler som i dag ikke har full dekning av innbo og læremidler etter de nye kravene, får supplert utstyret i løpet av en treårsperiode» (s. 368). Hvem som skal betale for en eventuell nødvendig supplering nevnes ikke. Listene over nødvendige redskap, verktøy og maskiner under faget Forming deles inn i kategoriene Tekstilforming, Tre- og metallforming, Forming/Tegning, Hobby, Keramikk, Malerom samt Studierom (fagbibliotek og film/lysbilder) (s. 373-374). Den frie formingens læremidler kategoriseres altså også ut fra den materialbaserte inndelingen til de tre ferdighetsfagene fra før 1960. Over flere spalter listes det opp alt fra gimpenåler, brikke- og bordvever til gjengeverktøy, høvler, kniver og bandsag (til bruk for læreren). Under Tekstilforming kvantifiseres det tre symaskiner pr. rom på barnetrinnet og fem maskiner på ungdomstrinnet. Innbo deles inn i de samme kategoriene hvor det listes opp innbo som symaskinbord, strykefjel, høvelbenker, syreskap med spesiallås. Her finnes i tillegg kategorien Materialrom (lager) hvor blant annet hoggestabbe står på lista.

Punkt 2 har overskriften Allsidig utvalg av formingsmateriell. Hva som menes med Allsidig formingsmateriell vises under Eksempler på aktuelle materialer for de ulike klassetrinn hvor det listes opp hele 67 ulike materialer, alt fra vannfarge og temperablokk til materialrester og skrap fra for eksempel verksteder og bygg (KUD, 1974, s. 240-241). Materiallista er kodet med utgangspunkt i hvor aktuelle de ulike materialene er på ulike klassetrinn. Det understrekes i teksten at lista ikke er et absolutt krav, og det beordres med påbud at skolen selv må ha frihet til å tilpasse materialene ut fra lokale forhold (s. 240). Videre på samme side erkjennes det at formingsundervisningen på denne måten vil kreve stor lagerplass. Det foreslås også ulike måter å lagre materialene på, fra åpne hyller i aktivitetsrommene til hovedlager i egne materialrom. Stablebare kasser og hyllevogner med store svingbare hjul beordres med gjerne. 
Punkt 3 peker på tidsmessig audiovisuelt utstyr, blending og rikt bildeutvalg. Punkt 4 peker på rikelig utstillingsplass. Og, til slutt, punkt 5 som peker på inspirasjonsstoff i form av håndbøker, litteratur og trykt materiell med tilrettelagte arbeidsoppgaver (s. 240). Ingen av punktene inneholder tallfesting av størrelser på spesialrom for faget Forming.

Under overskriften Vurdering henvises det først til M74s generelle del, deretter kommer det en beordring om at vurderingen skal ta utgangspunkt i skolens generelle målsettinger, fagets målsettinger og elevens forutsetninger. En må også ta hensyn til de undervisningsmetoder og arbeidsformer som er nyttet (KUD, 1974, s. 241). Hensynet til elevens personlige forutsetninger begrunnes i den generelle delen av planen som sier at «[...] grunnskolen er en skole for alle, ikke en skole for elever som er utvalgt med tanke på allerede oppstilte undervisnings og oppdragelsesmål» (KUD, 1974, s. 59). Når et mål i faget er at undervisningen skal ta sikte på å øve opp praktiske ferdigheter (s. 236) skal derfor det utførte håndverket i et produkt også vurderes ut fra elevens forutsetninger samt anvendte undervisningsmetoder og arbeidsformer. Hensynene som pålegges når det vurderes kan slik veie opp for et dårlig utført håndverk. Fagmålet med sikte på å øve praktiske ferdigheter peker heller ikke på hvilke praktiske ferdigheter som skal læres. Det er rimelig å tenke at når det beordres at man skal ta hensyn til personlige forutsetninger, undervisningsmetoder og arbeidsformer, svekkes betydningen av de praktiske ferdighetene i vurderingen og også insitamentet til å utforme og bygge spesialrom for faget.

Deretter kommer en veiledende arbeidsplan for de ulike trinnene i grunnskolen (KUD, 1974, s. 241-251). Planen er på 10 sider, skisserer i stikkordsform eksempler på arbeidsoppgaver og har ingen inndelinger i fagdisipliner som tegning/maling, tekstil, leire/keramikk, eller (tre)sløyd. Planene for årstrinnene 4-6 og 7-9 har ordnet oppgavene under overskriftene Fabulering, Følelsesuttrykk, Saklig fortelling, Dramatisk virksomhet, Oppfinnsomhet, Konstruksjon, Funksjon og Dekor. Håndverk og nødvendigheten av verktøy og utstyr kommer til uttrykk i arbeidsplanen når fagord og begreper anvendes, som for eksempel plattsøm, veving, applikasjon, fargeklang, klinking og sammenføyning. Også spesifikke verktøy nevnes som for eksempel symaskin. Det finnes ingen beordringer om hvordan spesialrom skal være utformet.

\section{NOU 1975: 40: Planlegging og utforming av undervisningsbygg}

I 1975 kom NOU: 40: Planlegging og utforming av undervisningsbygg skrevet av det oppnevnte Utvalget for undervisningsbygg. Flere av medlemmene i utvalget hadde bakgrunn som pedagoger/lærere, men jeg har ikke funnet at noen hadde bakgrunn i faget Forming. Arkitektene ble representert med gjenreisningsarkitekten Odvar Hedlund.

I denne NOU-en framgår det at formingsfaget for årstrinn 1-3 i høy grad «[...] er et middel til å ut|øse barnas trang til å gi sine inntrykk fra andre fag synlig form» (NOU 1975: 40, s. 23). Videre står det at Forming derfor $b \varnothing r$ integreres med de andre fagene i det ordinære klasserommet som da $b \varnothing r$ ha et noe større areal enn normalt (s. 23). $75 \mathrm{~m}^{2}$ oppgis å være «tilstrekkelig». Videre foreslås innredning av formingskrok i dette større klasserommet. Fra årskull 4 framgår det at elevene skal ha tilgang til et eget formingsrom slik at de kan arbeide med støy-og støvframbringede aktiviteter. Her pekes det også på behovet for lagerplass. Samlet ansees det å være tilstrekkelig at formingsavdelingen har et totalareal på $100 \mathrm{~m}^{2}$ (s. 23). På ungdomstrinnet peker utredningen på at elevene trenger egne spesielt utstyrte formingsrom hvor de skal gis muligheter til fordypning og å arbeide med forming som fag med sin egenverdi (s. 23). Hva fagets egenverdi er utdypes ikke. Av hensyn til fagintegrering bør formingsrommene legges i tilknytting til det $\varnothing$ vrige arealet. Samtidig presiseres det at de ulike rommene $s k a l$ utgjøre en avdeling - en enhet, med direkte forbindelse til alle rom. Dette begrunnes med at «Elevene må ha adgang til å nytte alle rom dersom arbeidsoppgaven tilsier bruk av utstyr i tilstøtende rom» (NOU 1975: 40, s. 23).

Videre i utredningen regnes det ut, med utgangspunkt i datidens rammetimetall, at det er et behov for ca. 28 romtimer per uke på en fulldelt 9-årig skole (NOU 1975: 40, s. 24). Arealdisponeringen av de ulike verkstedene som foreslås vises i figuren under (figur 6). 
En vil foreslå følgende arealdisponering:

a. 1 verksted kombinert for tre- og metallarbeider ............. $100 \mathrm{~m}^{2}$ Materiallager .............. 40 》 Oppbevaring for malte gjenstander $15 \gg$ Rom for gjenstander under arbeid 15 》

Sum $170 \mathrm{~m}^{2}$

b. Hobby- og keramikkovn med tørkerom ................ $40 \mathrm{~m}^{2}$ Rom for keramikkovn ........ 5 » Fotorom ............... 15 ,

Sum $60 \mathrm{~m}^{2}$

c. Kombinert rom for tegning/maling og tekstilforming ........... $100 \mathrm{~m}^{2}$ Lager $\ldots \ldots \ldots \ldots \ldots \ldots \ldots \ldots, 20$ »

Sum $120 \mathrm{~m}^{2}$

Samlet areal for formingsavdelingen ............... $350 \mathrm{~m}^{2}$

FIGUR 6. Arealdisponering for formingsrom på ungdomstrinnet fra NOU 1975: 40, (s. 24).

Det er interessant at NOU 1975: 40 både definerer romfunksjoner og tallfester arealene til spesialrom for faget på ungdomstrinnet, men ikke begrunner valg av romtyper eller st $\varnothing$ rrelsen på disse. Inndelingen ut fra materialene tre/metall, keramikk og tegning/maling tekstil ligner på inndelingen i de tre fagene før sammenslåingen til Forming. Arealene som oppgis i utredningen fra 1975 er vesentlig større enn arealene jeg ser ute i skolen i dag. Interessant er det også at bruk av formingskrok i de ordinære klasserommene på de lavere årstrinnene begrunnes i at faget der først og fremst er en metode; å gi sine inntrykk i andre fag synlig form.

\section{Grunnskolerådets ERFA nr. 20: Planlegging og utforming av skolebygg Grunnskolen}

Fire år etter NOU 1975: 40 om utforming av undervisningsbygg gir Grunnskolerådet ut et ERFA-hefte med tittelen: Planlegging og utforming av skolebygg Grunnskolen (Grunnskolerådet, 1979), der de deler opp rommene i ulike type arealer/soner tilpasset tre aldersgrupper ut fra ulike typer aktiviteter som vist i figuren under (figur 7).

I en 1-6-skole anbefaler Grunnskolerådet at formingsundervisningen vanligvis bør foregå i en formingskrok i klassearealet på de laveste trinnene 1-3 (Grunnskolerådet, 1979, s. 53). Fra og med 4. årstrinn er det Ønskelig med et større areal, gjerne delt opp med skillevegger (s. 54). Begrunnelsen er at forming på disse klassetrinnene «[...] krever noe mer variasjon, materialer, verktøy og utstyr, og arealbehovet er derfor st $\varnothing$ rre» (s. 53). Utstyrskrevende spesialutstyrte rom beskrives i arealprogrammet først på ungdomstrinnet under atskilt formingsavdeling på 1-9- og 7-9- skoler (s. 54-56). Her avhenger arealst $\varnothing$ rrelsen av hvor mange paralleller som finnes på hvert trinn. Gjennomgående deles arealene inn ut fra arbeidsområdene; tegne-, tekstil-, og sløydaktiviteter. Det beordres at på slike arealer må mulighetene også legges til rette for integrering med andre fag (s. 54).

Dersom det er to klasser på hvert trinn på en 1-9 skole, er forslaget at arealet skal være $160 \mathrm{~m}^{2}$ fordelt over to arealer. Ett areal for grovere formingsaktiviteter som tre og metall, og ett for tekstilforming. Begge arealene tenkes med tilst $\varnothing$ tende lagre. Med tre klasser på hvert trinn er forslaget $270 \mathrm{~m}^{2}$ med $90 \mathrm{~m}^{2}$ på hvert av arealene tekstilforming, tegning maling og lettere sløydaktiviteter samt tre/ metall og grovere sløydaktiviteter. Det er også satt opp eksempler på alternative arealdisponeringer. 
Med en klasse på hvert trinn foreslår Grunnskolerådet et areal på $350 \mathrm{~m}^{2}$ fordelt på tre/metall, hobby/ keramikk/foto og tegning/maling/tekstil. Her er det avsatt arealer for lagring av materialer og elevarbeider samt ovnsrom. Til slutt vises et eksempel på fem klasser på hvert trinn hvor totalarealet oppgis til $600 \mathrm{~m}^{2}$. Her er tekstilforming delt opp i to arealer med plass til veving på det ene arealet og tegning/maling på det andre, og det er satt av plass til lagring og oppbevaring.

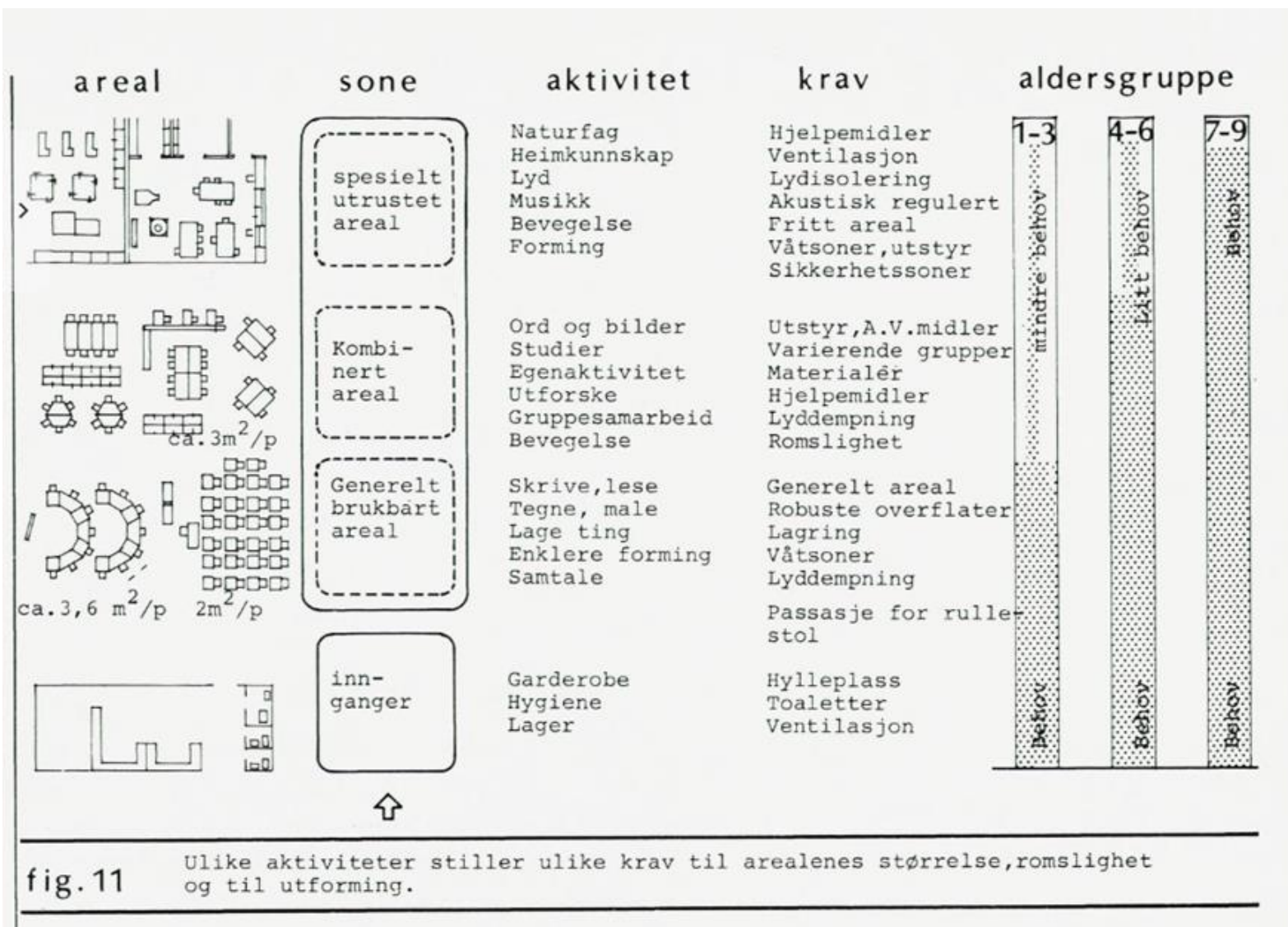

FIGUR 7. Grunnskolerådets forslag til oppdeling av areal, soner og aktiviteter fra 1979. Årstrinnene 1-3 kan greie seg med generelt brukbart areal, 4-6 har behov for kombinert areal, mens 7-9 trenger spesielt utrustet areal. (Grunnskolerådet, 1979, s. 27).

\section{Grunnskolerådets ERFA nr. 29: Fagarealer i grunnskolen}

I 1983 ga Grunnskolerådet ut et nytt ERFA-hefte med tittelen: Fagarealer i grunnskolen. Heftet tar utgangspunkt i veiledende arealnormer for grunnskolebygg som er oppgitt i Kirke- og Undervisningsdepartementets rundskriv F-100/78 (KUD, 1978, s. 4-5) samt i Grunnskolerådets eget ERFA-hefte fra 1979. Grunnskolerådet drøfter i dette heftet fra 1983, blant annet spørsmål rundt innredning av arealer med behov for spesielt utstyr og fagintegrering. Reidun Lien og Kenneth Skaar er oppgitt som sakkyndige for faget Forming. Under Forming vises det først til Mønsterplanen og hovedsiktepunktet for formingsundervisningen (Grunnskolerådet, 1983, s. 67-68). Deretter utledes under Utforming av arealet at

Elevenes skapende virksomhet skal være det sentrale i formingsundervisningen. Hovedkravet til fagarealet til forming må derfor være at det er utformet med tanke på å gi elevene frihet til å velge mellom flest mulige varierte aktivitetstilbud. (Grunnskolerådet, 1983, s. 68)

I ERFA-heftet peker Grunnskolerådet også på at det må legges til rette for integrering med andre fagområder og at en inndeling i egne fagarealer «[...] neppe vil gi elevene de beste muligheter for valg av formingsaktiviteter» (Grunnskolerådet, 1983, s. 68). Grunnskolerådet understreker i heftet at en slik inndeling strider mot Mønsterplanens intensjon hvor Forming er ett fag, og at dette også kan begrense 
«[...] mulighetene for integrert undervisningsopplegg på tvers av faggrensene (s. 69). Deretter presenteres det i samme hefte, på sidene 69-73, tre figurer som viser ulike måter å plassere de ulike fagarealene i forhold til hverandre på. I den første varianten ligger sløydforming, tegneforming og tekstilforming på rekke og rad med egen inngang til hvert rom, noe Grunnskolerådet mener vil innby til en tredeling av faget. I den andre varianten er dette forsøkt hindret ved at det er laget en åpning mellom de ulike rommene. Grunnskolerådet fremhever til slutt en bedre tredje variant hvor de ulike rommene er organisert i en klynge med åpninger mellom sløyd- tegne- og tekstilforming som skissert i figuren under (figur 8). Grunnskolerådet forsøkte på denne måten å utforme fagarealene slik at de skulle støtte opp om mønsterplanens ideer om elevens frie utfoldelse i Forming.

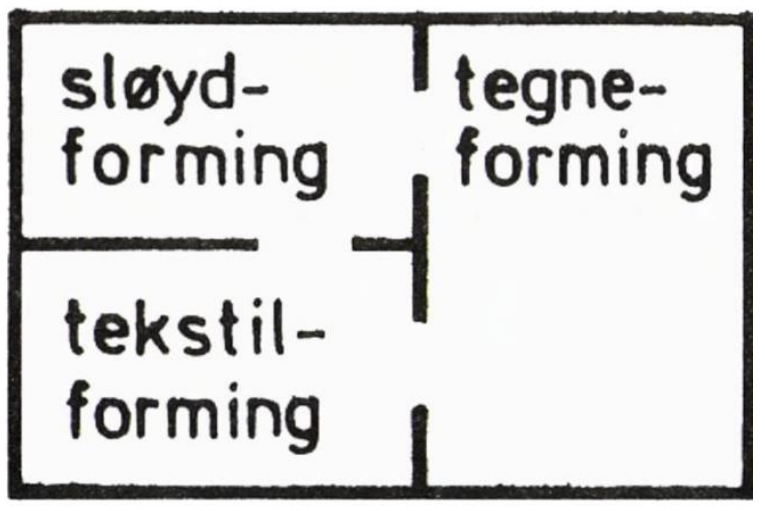

FIGUR 8. Figur fra ERFA 1983, Fagarealer i grunnskolen, hvor de ulike fagarealene er organisert i en klynge og med åpninger mellom de ulike fagarealene (Grunnskolerådet, 1983, s. 70).

\section{Grunnskolerådets hefte: Forming. Innstilling fra en arbeidsgruppe (1984)}

Etter en læreplankonferanse høsten 1983 ba Kirke- og Undervisningsdepartementet Grunnskolerådet om å legge fram et utkast til en revidert mønsterplan. En av begrunnelsene var at M74 var for omfangsrik og detaljstyrende. Bærende prinsipper skulle beholdes, men fagplanen måtte forenkles (Grunnskolerådet, 1983, s. 1). Grunnskolerådet nedsatte en arbeidsgruppe som leverte sitt arbeid: Forming. Innstilling fra en arbeidsgruppe i 1984. I innledningen peker medlemmene i gruppa på at de i hovedsak har brukt egen erfaring som grunnlag for vurdering og debatt da de manglet tilgang på bredt empirisk materiale (Grunnskolerådet, 1994, s. 2). I innstillingen detaljeres ikke materialer og teknikker, men det presiseres at faget «[...] handler om å lage noe med egne hender i konkrete materialer» (s. 23). I vedlegget til innstillingen; Om det materiale/tekniske, det estetisk skapende og det erkjennende, pekes det på at Forming er et materialfag og at til tross for at vi er avhengige av den materiale verden, så er ikke dette anerkjent som spesielt betydningsfullt (Grunnskolerådet, 1984, vedlegg s. 1). Under overskriften Det tekniske presiserer utvalget at

Hvert materialområde vil ha et eget sett av tekniske ferdigheter knyttet til seg. Det å tilegne seg denne ferdighet er en av nøklene til å bringe råstoffet ut av sin anonymitet, til å gjøre det til det det er, til å forene råstoff og ide. (Grunnskolerådet, 1984, vedlegg, s. 3)

Innstillingen inneholder ingen konkretiseringer av hvilke typer materialer, verkt $\varnothing y$, utstyr og typer rom som kreves for å kunne forene råstoff og ide.

\section{Mønsterplanen for grunnskolen 1987 (M87)}

M87 ble både i forkant og når den ble lansert kritisert for å være for ambisiøs. «Lærerorganisasjonene kritiserte særlig misforholdet mellom planens krav og rammevilkårene i skolen og mange lærere sendte planen tilbake til departementet» (Kjosavik, 2003, s. III). Av beordringer som peker på praktiske ferdigheter og spesialrom finner vi i fagplanens seks mål at undervisningen skal ta sikte på «- å gi elevene erfaring med hensiktsmessige materialer og teknikker og øve opp praktiske ferdigheter» (KUD, 1987, s. 
263). De фvrige målene er affektive, hvor elevens skapende arbeid er et middel til å utløse engasjement, stimulere følelse, fantasi og tanke, utvikle varhet, kritisk sans, forståelse samt stimulere til handling og oppdra til medansvar. Ingen av målene presiserer hvilke materialer verktøy og teknikker elevene skal oppøve praktiske ferdigheter i å bruke.

Under lærestoff og progresjon i M87 deles faget opp i hovedemner uten å nevne tradisjonelle materialer og teknikker. Det pekes på at «Planen sikter mot progresjon ved å utvide og differensiere elevenes erfaringer med grunnleggende materialer, teknikker og redskaper» (KUD, s. 264). Hva som menes med grunnleggende materialer, teknikker og redskaper presiseres ikke. Videre kan en se at «Skolen må stimulere «gjør det selv» - virksomheten som i dag gjør seg stadig mer gjeldende i tilknytning til hus, hytte, redskaper, maskiner o.a.». Dette begrunnes med at «Praktiske erfaringer med slikt arbeid kan bidra til å utvikle sans for kvalitet og økonomi» (s. 264).

På samme side pekes det på at stoffomfanget er stort og at det må tas hensyn til at oppøving av praktiske ferdigheter tar tid. Årsplanene oppover i klassene $b \varnothing r$ derfor gi anledningen til å gå i dybden på de høyere trinnene «[...] og til å arbeide med sentrale materialer og teknikker som elevene lærer å bruke og beherske» (KUD, 1987 s. 264). På side 265 finner vi at «Det bør legges vekt på progresjon i bruk av teknikker og materialer: tre, tekstil, leire, metall og materialer for tegning, maling og grafikk.» Her nevnes altså materialområder som peker på tidligere faginndelinger og med et tydelig fokus på utvikling av håndverksferdigheter. Med hensyn til bildeforming pekes det på at «Det håndverksmessige, det estetiske og det uttrykksmessige kan her være utgangspunkt for oppgaver» (s. 265).

Under overskriften Arbeidsmåter (KUD, 1987, s. 265-266) legges det vekt på skapende praktisk arbeid med fokus på variasjon, samarbeid, tverrfaglighet og prosjektarbeid. Her finnes også fire strekpunkter om vurdering; to peker på det affektive (personlig uttrykk, holdninger og engasjement), og to på ferdigheter knyttet til håndverk og formspråk; «- tekniske og praktiske ferdigheter og innsikt i arbeidsprosesser», samt «- bruk av, forståelse av og vurdering av estetiske virkemidler» (s. 266).

Under overskriften Rom utstyr og læring forutsetter M87 at arbeidsarealene er i nærheten av hverandre. Dersom det ikke er slike forhold, anbefales det gjennom modal beordring at rommene $b \varnothing r$ omorganiseres (KUD, 1987, s. 266). Med hensyn til materialer beordres det at «Et hensiktsmessig utvalg av materialer er vesentlig for å arbeide med faget. Det er nødvendig med god og oversiktlig lagringsplass» (KUD, 1987, s. 267). Det er rimelig å tolke vesentlig og nødvendig som påbud. Videre anbefales det gjennom modal beordring at vinduene i minst ett av formingsrommene bør kunne blendes, at rommene $b \varnothing r$ ha utstillingsplass for elevarbeider, samlinger og utvalg av litteratur, og at det $b \varnothing r$ være tilgang til tidsmessig audiovisuelle utstyr (s. 267). Med andre ord vil det å hente slikt utstyr fra et annet rom falle innenfor det anbefalte. Angående redskaper, verkt $\varnothing y$, maskiner og utstyr anbefales det gjennom modal beordring at

Formingsavdelingen vil være utstyrt med redskaper, verktøy, maskiner og hjelpemidler som trengs for de forskjellige aktivitetene. Spesielt der yngre elever benytter klasserom til forming $b \varnothing r$ det være utstyr og redskaper til arbeid med harde og myke materialer. En måte å organisere materialene på er å dele inn klasserommet i stasjoner eller arbeidskroker. (KUD, 1987, s. 267)

Man kan undres over hvorfor det her beordres med vil og $b \varnothing r$ og ikke et skal. Utstyret knyttes ikke til bestemte teknikker eller håndverk, men til aktiviteter samt harde og myke materialer. Skolene gis på denne måten et stort handlingsrom og kan velge materialer og aktiviteter som er rimelige og/eller lite utstyrskrevende. Deretter beordres det med påbud at rommene må innredes for å unngå helseskader. «En må sørge for å sikre maskiner, se til at de har avsug der det er helsefarlige gasser og støv, og at det er isolert mot høyt støynivå og sterk lyskonsentrasjon» (KUD, 1987, s. 267). Med andre ord beordres helse, miljø og sikkerhet, i motsetning til læring av ulike håndverk, med påbud.

Under overskriften Hovedemner deles faget inn i delemnene bildeforming, skulpturforming, bruksforming og forstå og vurdere bilde skulptur og bruksform. Under hvert av disse delemnene finnes en innledende beskrivelse av delemnet samt beskrivelser av faginnhold og ulike aktiviteter eleven tenkes å møte, forstå eller gjøre. Formen ligner den veiledende arbeidsplanen i M74; beskrivelsene er generelle, uten beordringer og svært omfattende. Beskrivelser som kan peke på behov for spesialrom, men 
hvor dette ikke beordres med påbud, finnes under bildeforming, skulpturforming og bruksforming. Under Materiale og teknikk, finnes for eksempel: «Grafikk, bearbeide trykkplater, papp, lino, tre, isopor» (KUD, 1987, s. 268). «Hogd eller skåret skulptur: enkel verktøybruk» (s. 269), «Prøve ut materialer som er grunnleggende for arbeid med bruksform: tekstil, tre leire» (s. 270), «Lære sammensetningsmåter, skru, spikre, veve, sy, strikke, hekle, lodde, nagle» (s. 271), og «Progresjon i bruk av redskaper og maskinelt utstyr» (KUD, 1987, s. 271). Målene er svakt innrammede; leseren må i stor grad selv utlede og avgjøre hvilke materialer, verktøy, utstyr og teknikker som skal inngå i eller være gjenstand for undervisning.

I den innledende teksten under bruksforming beordres det som påbud under Hovedemner og delemner for faget at «Det må legges vekt på godt håndverk» (KUD, 1987, s. 270. Dette begrunnes med at det $\varnothing k e r ~ «[\ldots]$ bruksformenes estetiske og funksjonelle verdi [...]» (s. 270). Videre på samme side anbefales det modalt at det oppover i klassene «[...] bør legges vekt på mer analytiske arbeidsmåter, og på at elevene får vurdere hva som er verdifullt for utforming av vårt miljø. Samtidig må en være åpen for spontane formvalg.» Med andre ord må ikke en analytisk tilnærming hindre spontane formvalg. At spontane formvalg kan være i konflikt med godt håndverk og funksjonelle verdier problematiseres ikke.

\section{Handlingsplanen for styrking av de estetiske fagene i skolen (1991)}

I 1991 utga Grunnskolerådet i samarbeid med representanter fra Norsk kulturråd, Norges Kunstnerråd, Bergen Lærerhøgskole og Samarbeidsutvalget for landslagene estetiske fag i skolen Handlingsplan for styrking av de estetiske fagene i skolen: inntrykk - uttrykk - avtrykk. Handlingsplanen reflekterer over begrepet praktisk estetiske fag og begrunner fagene blant annet ved å fremheve betydningen av kreativitet og den estetiske dimensjon (Grunnskolerådet, 1991, s. 5). Handlingsplanen kan ses på som et uttrykk for at de involverte fagmiljøene opplevde at faget stod svakt i skolen. På skolenivå konkluderer handlingsplanen med 12 anbefalende tiltak i form av den modale beordringen bør (s. 19-20), blant tiltakene er utvikling av planer, Idémateriell og læremidler. Bare ett av de tolv tiltakene handler om fysiske rammer for de estetiske fagene: «Estetiske fag er aktivitets- og handlingsfag. Midler til oppdatert utstyr og materiell bør prioriteres. Det er en fordel at konsulenter for estetiske fag er med i planleggingen av nye skolebygg» (Grunnskolerådet, 1992, s. 19). Handlingsplanen peker altså på et behov for styrking av spesialrommene, men detaljerer det ikke utover oppdatert utstyr og materiell. Det anbefales modalt at materiell bør prioriteres og at det er en fordel å benytte seg av konsulenter for estetiske fag i planleggingen av nye skolebygg. Ingen av delene beordres med må.

Grunnskolerådet ble nedlagt i forbindelse med en omorganisering av den statlige utdanningsadministrasjonen i 1992. Ny organisering bestod av Kunnskapsdepartementet, Nasjonalt læremiddelsenter (NLS), Eksamenssekretariatet ved Statens utdanningskontor i Oslo og Akershus (SUE) og Statens utdanningskontor i hvert fylke (Arkivportalen, 2017). Jeg har ikke funnet sentrale føringer til utforming av spesialrom for faget etter at Grunnskolerådet ble nedlagt.

\section{HVA KAN VI LAERE AV RETNINGSLINJENE FOR SPESIALROM FRA 1889 TIL 1992?}

To hovedperioder skiller seg ut i det materialet jeg har analysert. Den første perioden er fra 1889 fram til 1960 med de tre fagene Håndarbeid for jenter (tekstil), Håndarbeid for gutter (tre og metalls $\varnothing y d$ ) og Tegning. Den andre perioden er fra 1960 til 1992 når de tre fagene er samlet i faget Forming.

I den første perioden, hvor fagene ble begrunnet ut fra at de hadde praktisk nytteverdi for det praktiske liv (Nielsen, 2019, s. 53), var fokuset i retningslinjene på håndverk og innøving av praktiske ferdigheter. Perioden var preget av en stadig $\varnothing$ kende mengde av sentrale beordringer om verkt $\varnothing y$ og utstyr i de tre fagene og også om spesialrom for de to håndarbeidsfagene. Mot slutten av denne perioden knyttet Kirke- og undervisningsdepartementet (KUD) til seg fagkonsulenter som fungerte som rådgivere ute i skolen. Beordringene var i form av påbud og forbud, eller de var modale i form av anbefalinger med for eksempel kan, helst eller bør. I materialet fra hele den første perioden synes beordringene å lene seg på faglig erfaring og tradisjon. At fagkonsulenter etter hvert ble involvert, kan ha vært en styrking av fagligheten fram mot slutten av perioden. 
At folkeskolelovene av 1889 ikke inneholdt krav til spesialrom utover fornødent innbo som er nødvendig til felles bruk i undervisningen kan ha flere årsaker som for eksempel manglende økonomi i skolen eller at lovgiverne ikke tenkte det var nødvendig med et detaljert lovpålagt påbud. Det kan også tenkes at de $\varnothing$ nsket at dette skulle vurderes og bestemmes lokalt.

Normalplanene for landsfolkeskolen fra 1922 (N22) inneholder både beordringer om læremidler, verktøy og utstyr og tallfestede anbefalinger på hvordan spesialrom for faget Sløyd bør være utformet. I planens beskrivelser av undervisningen i presens kan en fagkompetent utlede nødvendig verktøy, materialer og utstyr. Også beskrivelsene i planen kan oppfattes som beordringer da de er i henhold til Normalplanen. Til tross for beordringene og beskrivelsene i N22, viser statistikken fra 1936/37 at 3800 skoler manglet sløydlokaler (Grunnskolerådet, 1983, s. 16-17). Mangelen på spesialrom var antagelig størst på bygdene fordi folkeskoleloven her åpnet opp for å tilpasse fagomfanget ut fra økonomiske hensyn (Lov om Folkeskolen paa landet, 1896, s. 429). Samtidig kunne elevene på landet, i motsetning til i byene, i større grad lære seg nyttig håndverk hjemme. De økonomiske nedgangstidene på 30-tallet kan være en medvirkende årsak til at spesialrom for sløyd ble nedprioritert. Andre årsaker kan være manglende vilje til å prioritere faget, misoppfatninger av læreplanen eller mangel på kompetente lærekrefter. Uansett førte ikke beordringene i læreplanen til bygging av spesialrom for de håndverksbaserte fagene.

I Normalplanen for byfolkeskolen 1939 (N39) finnes det et tydelig skifte i synet på faget Tegning. Den tidligere vektleggingen av iaktakelsestegning og læring av teknikker som perspektivtegning frarådes i N39 fordi det angivelig hindrer forestillingstegning som uforstyrret uttrykk (KUD 1939, s. 171). De få beordringene i N39 om materialer, verktøy og utstyr i faget Tegning kan ha sammenheng med frarådingen av å lære teknikker i faget. I fagene Håndarbeid for jenter og Håndarbeid for gutter finnes det derimot beordringer som påbyr at elevene skal kunne ulike typer håndverksteknikker samt anvende ulike nødvendige redskaper og verktøy (s. 182). Samtidig advarer planen her om at dette ikke må gå på bekostning av formingsarbeidet. I N39 finnes det i motsetning til i N22, ingen direkte anbefalinger i form av modale beordringer om hvordan spesialrom for fagene bør eller skal være. Det er altså opp til den enkelte skole å utlede dette fra fagplanene. Da planen gjelder for skoler i byene, hvor tilgangen på kompetente lærekrefter sannsynligvis var st $\varnothing$ rre enn i skolene på landet, fantes det antagelig flere lærere som kunne gjøre de nødvendige utledningene fra fagplanen.

Jeg finner det interessant at N39 anbefaler modalt at det som regel ikke bør være flere enn 15 elever på hvert sløydparti (gutter) og at det heller ikke bør være flere enn 15 elever på hvert Håndarbeidsparti (jenter) (KUD 1939, s. 185). Det oppgis ingen begrunnelser for begrensningen, men det kan tenkes at lærere i de to håndverksfagene har nådd fram med sine didaktiske tradisjoner og erfaringer $\mathrm{i}$ læreplanutformingen. Det er interessant i seg selv at begrensningen også er satt for jentene uten at det her i like stor grad kan argumenteres ut fra helse, miljø og sikkerhet.

Etter 2. verdenskrig virker det som staten drev fram en utbygging av spesialrommene på landet ved å gjøre tre grep. Det første var å tydelig beordre minstekrav til hva elevene skulle kunne av ulike typer håndverk i Normalplanen for landsfolkeskulen fra 1947. Det andre var å ansette fagkonsulenter som kunne gi skolene råd om utforming av spesialrom, og det tredje var å gi ut rettlederen Typeplaner for skolehus i bygdene og knytte denne til statlige byggelån til kommunene. Fagkonsulentene fungerte som rådgivere ute i skolen. Det er rimelig å tenke at fagkonsulentene også ble involvert i utformingen av beordringene i rettlederen da de kunne trekke veksler både på egen kompetanse og den tette kontakten med praksis. Beordringene i rettlederen kan med andre ord også begrunnes ut fra fagkonsulentenes kompetanse og erfaringer i praksis.

Rettlederen inneholder mange beordringer, også modale i form av anbefalinger, til hvordan spesialrom for ferdighetsfagene Sløyd og Håndarbeid skal eller bør være utformet. Det er rimelig å tro at kommunene i størst mulig grad søkte å innfri beordringene i typeplanene, også de modale anbefalingene, for å få bevilget lån fra staten. At håndverkere i gjenreisningsperioden etter 2. verdenskrig var etterspurt arbeidskraft, kan være en mulig årsak til de tydelige beordringene om å lære håndverk og om hvordan spesialrommene skulle være utformet. Det synes som beordringene først og fremst var begrunnet ut fra samfunnsnytte og ikke ut fra pedagogiske ideologier. Beordringene, som i form av påbud og anbefalinger preges av detaljert kunnskap om hvordan spesialrommene skal eller bør være, kan også 
være et resultat av at de tidligere fagene hadde eksistert i mer enn 50 år og at en betydelig erfaringsbasert fagdidaktisk tradisjon var etablert. Jeg finner det interessant at det i typeplanene beordres at arealene til sløydrom som regel bør være rommelige, og at det beordres med påbud at det ikke må være mindre enn $4 \mathrm{~m}^{2}$ pr. høvelbenk (KUD, 1947b, s. 13). Til sammenligning er dagens norm for undervisningsrom, også spesialrom, 2,5 m² (Helsedirektoratet 2014, s. 18-19). Det kunne være interessant å unders $\varnothing$ ke om det finnes materiale som kan bekrefte eller avkrefte om de tre grepene førte til utbygging av spesialrom i henhold til typeplanene. Og i så fall, om spesialrommene fungerte etter intensjonene.

I perioden 1969-1992, var de tre fagene slått sammen til faget Forming. Diskursen som ble formidlet gjennom N39, om å ikke forstyrre elevenes formingsaktiviteter innenfor faget Tegning, får nå gjennomslag også i de delene av faget som har røtter i fagene Håndarbeid for gutter og Håndarbeid for jenter. I spissen for sammenslåingen sto Tønnes Sirevåg, lederen for fors $\varnothing$ ksplanen for 9-årig skole og tidligere rektor ved katedralskolen i Bergen. På kurset i skolebygging ved NTH i 1958 uttrykte han et syn på faget som et trivsels-, hobby- og metodefag. Tønnes Sirevåg begrunnet ikke faget ut fra samfunnsnytte. Det er nærliggende å tenke at han, med hovedfag i historie som utdanningsbakgrunn, ledet arbeidet med læreplanen og defineringen av faget Forming ut fra et akademisk ståsted. Innlegg på NTH kurset viser samtidig at ledende krefter innenfor fagmiljøene i de tre fagene som nå skulle slås sammen var i tvil om hva det nye faget Forming skulle være (Dalaker \& Bastiansen, 1959). På kurset inviterte rektoren ved Statens sløyd- og teiknelærarskole (SSTL) på Notodden arkitektene, ikke bare til å mene noe om hvordan de nye spesialrommene skulle se ut, men også til å være med på å definere faget. Dette, samt fagsynet som kommer til uttrykk fra lederen for forsøksplanen fra 1960, kan tyde på at defineringen av faget Forming var sterkt preget av krefter utenfor fagmiljøene i de tre sammenslåtte fagene.

Fors $\varnothing$ ksplanen (F60) viser et tydelig skifte i perspektiv fra håndverk og nytteverdi til fokus på faget som metode for trivsel, personlig utvikling og læring i andre fag. Dette kommer til uttrykk i F60 ved at innøving av håndverksferdigheter ikke lenger er selvstendige mål i formingsarbeidet (KUD, 1960, s. 292) og ved at det innføres med påbud at det skal tas hensyn til både lærerkrefter, elevens læreforutsetninger og hva som har vært tilgjengelig av verktøy, materialer og utstyr når det settes karakter (KUD, 1960, s. 291). Det betyr at betydningen av å ha lært teknikker og håndverk svekkes kraftig, dermed også hvordan spesialrommene utformes.

For å gi elvene et fritt valg ut fra et indre uttrykksbehov legges det i F60 vekt på et bredt materialtilfang, noe som krever både bredde i ulike verktøy og god lagerplass. Hvilke verktøy og utstyr dette gjelder spesifiseres derimot i liten grad. Tidligere læreplaners beordringer om ferdigheter i bruk og vedlikehold av spesifikke verktøy og utstyr er fraværende. Når håndverksmessig bruk og vedlikehold av (et bredt og fritt tilgjengelig utvalg) verktøy og utstyr er underordnet, er det fare for at spesialrommene nedprioriteres og forfaller. Selv om sløydlærere med solid fagfordypning fortsatt holder orden på og bruker sløydsalene i perioden (Nielsen, 2019, s. 80), viser ikke materialet at disse når fram med argumenterer for å beholde det tidligere fokuset på læring av håndverk. Her kan det være et frustrerende sprik mellom lærerens kompetanse og de nye beordringene i F60 - mellom formidling av håndverk og føringer i pedagogisk ideologi.

Skiftet kan også forklares ved at samfunnet endret seg fra å være dominert av primærnæringer

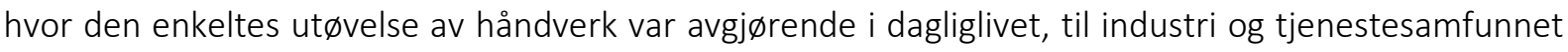
hvor artefakter i stor grad ble industrielt framstilt og kunne kjøpes i butikken. At ordet hobby (fritidssyssel) står i læreplanen underbygger at det er et syn på faget som lite viktig i seg selv. Kort sagt virker det som om fagsynet i Tegning fra N39 får dominere i hele faget Forming i F60, og at læring av håndverk og teknikker blir underordnet og til og med frarådet.

Det kan se ut som det nye fagsynet i planarbeidet, de økonomiske utfordringene i etterkrigstidens store skoleutbygging samt fagmiljøets tvil om hva det nye faget skulle være, til sammen førte til et fag hvor (dyre) spesialrom for læring av håndverksferdigheter ble nedprioritert. I skoleeiernes perspektiv var de tradisjonelle spesialrommene dyre. Arkitektene viste samtidig hvordan det kunne bygges billigere, ved å tilrettelegge de ordinære undervisningsrommene med formingskrok, ved å innrede $a k$ tivitetsrom hvor det kunne foregå tverrfaglig arbeid og ved å legge til rette for sambruk av spesialrom- 
mene. Tanken om å redusere kostbare spesialromarealer og gjøre dem fleksible i bruk kan kjennes igjen i utformingen av spesialrom for faget Kunst og håndverk i moderne skolebygg.

I denne perioden delegerer KUD i økende grad både tolkningen av læreplanen og hvordan læringsarealer skal være utformet. I 1966 opprettet KUD Folkeskolerådet, seinere med navnet Grunnskolerådet, som involveres både utforming av læreplaner og utgivelser av en rekke veiledere for rom til faget Forming. Beordringene i veilederne er basert på tolkninger av læreplanen (som de selv er med på å skrive), samt erfaring. Her finnes ingen forskningsbaserte begrunnelser for hverken arealnormer, utforming eller innredning av spesialrom. Å lene seg på erfaring kan være en styrke, men når erfaringene som ligger til grunn er skjulte, slik de er i ERFA-heftene, kan de heller ikke utsettes for granskning og kritikk. Grunnskolerådet beordret et rikt materialutvalg og formingsrom uten tydelige skiller mellom de tidligere materialhovedområdene tre, tekstil og tegning. De ulike arealnormene som oppgis for ulike trinn og antall paralleller peker på at arealene i størst mulig grad må utnyttes, enten gjennom å ta hensyn til antall paralleller og eller ved sambruk. For fådelte skoler ble det anbefalt mindre arealer og i større grad formingsaktiviteter i vanlige undervisningsrom. På de lavere trinnene ble det beordret formingskrok i det vanlige undervisningsrommet. Grunnskolerådet ga også råd til mer tverrfaglig formingsarbeid i det ordinære undervisningsrommet på de lavere trinnene og mer av det de kalte ren forming $\mathrm{i}$ spesielt utstyrte rom på ungdomstrinnene. De definerte ikke hva de mente med ren forming, og de begrunnet heller ikke at elever på småtrinnene ikke trengte spesialrom utover at det var naturlig (Grunnskolerådet, 1972, s. 5-6). Jeg finner dette svært interessant da jeg har sett at det også i dag er langt mellom spesialrommene på de lavere trinnene. Samtidig er mine erfaringer fra undervisning på 5 . trinn at elever i denne alderen både er svært motiverte og mottakelige for å lære teknikker og håndtering av verktøy.

I læreplaner, veiledere, rapporter og styringsdokumenter for faget Forming kommer det fram et syn hvor læring av håndverk og teknikker forstyrrer elevens naturlige og personlige utvikling og uttrykksbehov. Eleven skulle i størst mulig grad løse tekniske utfordringer uten hjelp fra lærer. Dette begrunnes ikke utover ideen om å ikke forstyrre barnets naturlige utvikling. Det finnes få beordringer med påbud i læreplanene knyttet til spesialrom for faget, men Grunnskolerådet ga ut flere detaljerte veiledere. Her er det sentralt at eleven skal presenteres for et bredt materialutvalg og selv velge formingsaktivitet ut fra et naturlig indre uttrykksbehov. Det beordres åpne spesialrom med et bredt utvalg materialer, verkt $\varnothing$ y og utstyr på tvers av de tidligere tre ferdighetsfagene. Helsemessige hensyn tas slik at for-

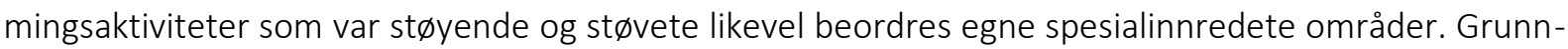
skolerådets veiledere viser mindre rom utstyrt for trebearbeiding hvor eleven fritt skal kunne velge verktøy og utstyr. Når det å lære håndverk ble underordnet frie formingsaktiviteter, er det rimelig å tenke at fri tilgang og bruk av verktøy og utstyr førte til feilbruk og manglende vedlikehold. Egne erfaringer fra praksis kan underst $\varnothing$ tte at konsekvensene ble et raskt forfall av spesialrommene.

Både i Typeplaner for skolehus på bygdene (KUD, 1946), på kurset i skolebygging ved NTH (Dalaker \& Bastiansen, 1959) og videre i Grunnskolerådets veiledere (Grunnskolerådet 1972, 1979 og 1983) formidles det et $\emptyset$ nske om å begrense arealene til spesialrommene. Argumentet bygger på rommenes lave utnyttelsesgrad og dyre innredning. Diskursen i faget Forming synes å passe godt inn i kravet om høyere utnyttelsesgrad da ideene som formidles tilsier at undervisning i håndverk ikke står i fokus og at undervisningen derfor i større grad kan foregå uten spesialrom. Generelle arealer for frie formingsaktiviteter skulle ha høy utnyttelsesgrad og derfor være lønnsomme - spesielle arealer for læring av håndverk hadde lavere utnyttelsesgrad og ble derfor ansett for å være for dyre.

Etter 30 år med faget Forming utgir Grunnskolerådet Handlingsplan for styrking av de estetiske fagene i skolen: inntrykk - uttrykk - avtrykk (Grunnskolerådet, 1991). En hurtigarbeidende gruppe bestående av representanter fra Grunnskolerådet, Norsk Kulturråd, Norges Kunstnerråd, Bergen lærerhøgskole samt Samarbeidsutvalget for Landslagene for estetiske fag i skolen utformer handlingsplanen. Her kommuniserer et bredt fagmiljø en erkjennelse om at faget både mangler et tydelig innhold og har lav status i skolen. I handlingsplanen reflekteres det på et ideologisk nivå over hva faget Forming er, og det blir foreslått 12 tiltak på skolenivå. Kun ett av tiltakene handler om spesialrom; det pekes på at midler til oppdatert utstyr og materiell bør prioriteres og at det er en fordel å bruke konsulenter fra estetiske fag i planleggingen av nye skolebygg (s. 19). Fagmiljøene innser i handlingsplanen at spesial- 
rommene må rustes opp, men synes ikke å vektlegge det særlig mye, og de har heller ikke formell makt til å beordre opprusting med påbud. Ut fra det innhentede materialet fra perioden er det nærliggende å tenke at nettopp nedprioriteringen av å undervise i teknikker og håndverkstradisjoner var en sentral årsak til at faget trengte en handlingsplan. Det kan derfor synes merkelig at handlingsplanen ikke i større grad vektlegger en opprusting av håndverkskomponenten i faget.

\section{HVORDAN KUNNE SPESIALROMMENE BLI SÅ NEDPRIORITERT?}

Den sentrale styringen av spesialrom for læring av håndverk nådde et toppunkt rett etter 2. verdenskrig. Da ansatte KUD fagkonsulenter og utga Typeplaner for skolebygg samt en læreplan (N39) med tydelige minstekrav til hva elevene skal kunne i Handarbeid for gutter og Handarbeid for jenter. Dette kan ha vært et uttrykk for det store behovet for håndverkere etter 2. verdenskrig. Styringen var da antagelig først og fremst motivert ut fra et samfunnsbehov. De mange beordringene kan også være et resultat av at det over mange år hadde vært bygd opp en erfaringsbasert fagdidaktisk tradisjon hvor faglæreres kompetanse hadde spilt en sentral rolle.

Synet på de to håndarbeidsfagene endret seg deretter forholdsvis raskt. I det studerte materialet skifter myndighetenes retningslinjer fra å beordre læring av håndverkstradisjoner og spesialrom for dette, til å beordre rom for frie formingsaktiviteter. Samtidig skjer det en ideologisk endring i begrunnelsen for fagets berettigelse i skolen fra å ha en legitimering gjennom opp øving av ferdigheter og samfunnsnytte til å bli legitimert som et metodefag som dyrket selvutvikling og avkobling i form av hobbysysler. Det kan ses på som en form for psykologisering av faget hvor håndverket skyves i bakgrunnen. Skiftet kan ha kommet av raske samfunnsendringer, av pedagogiske og ideologiske strømninger, og eller vært $\varnothing$ konomisk motivert. Men det kan også tenkes at det har vært et resultat av enkeltpersoners autoritet og påvirkningskraft, som da rektoren ved SSTL på Notodden, antagelig av ideologiske grunner, hevdet at man ikke skulle forstyrre barns naturlige vekst og uttrykksbehov med læring av håndverk og teknikker. På dette grunnlaget gikk han inn for å spare inn på spesialromarealene. Eller da lederen i det daværende Forsøksrådet for skoleverket gikk inn for hobbyverktøy i vanlige klasserom for å hindre at håndverksfagene skulle bre om seg på bekostning av andre fag.

Varslinger om denne endringens konsekvenser for spesialrommene ble uttrykt på NTHs kurs i 1958. Det er verd å merke seg at representanter fra fagfeltet signaliserte at de var usikre på hvilke konsekvenser sammenslåingen av fagene ville få og usikre på hva det nye faget Forming skulle bli. I stedet for å legge fram egne reflekterte syn på det nye faget og argumentere for utforming av spesialrom ut fra dette, sa de seg enige i at spesialrom ble for dyrt og presenterte hvordan dette kunne løses med fleksible romløsninger samt integrering innen formingsfagene og med andre fag. Momenter som armslag, tidsbruk til å gjøre om på romløsningene eller st $\varnothing \mathrm{v}$ og st $\varnothing y$ problematikk ble ikke løftet fram i presentasjonene fra kurset. Kort sagt virker det som om representantene for faget manglet faglig ryggrad.

Det ser ut som om døra stod åpen for å tilpasse det nye faget og behovet for spesialrom ut fra både et $\varnothing$ konomisk, ideologisk og fagautorativt perspektiv. Det virker i det hele tatt som myndighetenes og skoleutbyggernes ideer og argumentasjon om at faget var for dyrt og at nye skolebygg helst måtte bygges uten spesialrom med integrerte formingskroker i ordinære klasserom, stod uimotsagt. Dette kan også ses på som en skolepolitisk kamp: myndighetene ønsket å omprioritere bruk av ressursene, høvling og sying i faget Forming skulle ikke få bre om seg på bekostning av andre og viktigere fag. Grunnskolerådets veiledere, $i$ årene som kom, støttet i stor grad denne prosessen.

I styringsdokumentene for begge perioder, fra 1889 til 1960 og fra 1960 til 1992, er de fleste beordringene modale anbefalinger, de færreste har form av påbud. Når utforming av spesialrom blir anbefalt med modale beordringer som bør eller kan, åpner det opp for at skolen kan la være å følge direktivene. Modale beordringer gir på den ene siden rom for lokale tilpassinger, på den andre siden er det fare for at skoleeier ikke leser modaliteten ut fra et faglig ståsted, men med $\varnothing$ konomiske, personlige og eller ideologiske briller; de fagene rektor anser som viktigere prioriteres og kan samtidig være billigere å drive. Man kan spørre seg om den fagkompetente lærer som trenger et spesialrom i undervisningen da vil oppleve et frustrerende sprik mellom egen faglighet, det sentralt dirigerte bør eller kan og den 
enkelte skoles valg av slik. Det ville vært interessant i et videre arbeid å undersøke spesialrom på det gjennomførte nivået og se på i hvilken grad modale anbefalinger er fulgt og i tilfelle på hvilket grunnlag. At det i hele perioden (1889-1992) er få beordringer med påbud om hvordan spesialrom for faget skalvære utformet, kan også henge sammen med en mangel på didaktiske argumenter. Materialet fra hele perioden viser da heller ingen forskningsbaserte fagdidaktiske begrunnelser for hverken arealnormer, utforming eller innredning av spesialrom. Begrunnelsene synes først og fremst å lene seg på fagdidaktiske tradisjoner og erfaringer knyttet til håndverk. Mot slutten av perioden begrunnes beordringene mest ut fra pedagogiske tanker og ideer om faget som avkobling, metode for uforstyrret personlig vekst og som metode i andre fag.

Reorganiseringen av Grunnskolerådet i 1992 kan ses på som et sentralt skille i norsk skolepolitikk. I dag er det den enkelte kommune/skoleeier som ut fra opplæringsloven, læreplanen, forskrift om miljørettet helsevern, og byggteknisk forskrift (TEK17) bestemmer hvordan skoler og undervisningsrom skal utformes. Man kan undres over om kommunene har kompetanse og ressurser til dette. Det synes for meg som om utformingen av dagens spesialrom, ofte med store arealer for tegning, maling og tekstile materialer med transparente løsninger og mindre formingskroker for harde og plastiske materialer, er et resultat av de ideologiske strømningene og de sentrale føringene fra den gang faget het Forming.

Håndverksferdigheter er, når denne artikkelen skrives, et kjerneelement i læreplanen for grunnskolen (LK20) (Utdanningsdirektoratet, 2020), og ikke en metode slik det framstår i faget Forming (N60, M74, M87). Ferdigheter i bruk av verktøy og utstyr i myke, harde og plastiske materialer, står sentralt. I dette perspektivet er det viktig å kunne gi fagdidaktiske begrunnelser for hva som er gode spesialrom for faget. Et utgangspunkt for et videre forskningsarbeid kan være de ulike beordringene om utforming av spesialrom fra den gang faget var delt i tre, og håndverket stod i fokus. Et neste steg kan være å analysere kommunenes styringsdokumenter for skolebygg og se på i hvor stor grad føringene peker på relevante spesialrom sett i lys av læreplanen. Det kan se ut som om det trengs sentrale faglige råd og styringer når kommunene skal omgjøre vedtatte læreplaner til bygningsmessig virkelighet. 


\section{REFERANSER}

Arkivportalen. (2017). S-4F-11195 - Grunnskolerådet. https://www.arkivportalen.no/contributor/no-a145001000000629346 ?ins $=$ RA

Arnljot I. (1959). Rom for kombinert aktivitet i skolen. I M. Dalaker \& A. Bastiansen (Red). Skolebygging: http://urn.nb.no/URN:NBN:no-nb_digibok_2017020908019

Dalaker, M., \& Bastiansen, A. (Red.). (1959). Skolebygging: kurs ved NTH 1958. NTH. http://urn.nb.no/URN:NBN:no-nb_digibok_2017020908019

Dahl, E. \& Johansen R.O. (2006). Akantus. Vigmostad \& Bjørke.

Dahl, T., Askling B., Heggen, K., Kulbandstad, L. I., Lauvdal, T., Qvortrup,L., Salvanes, K. G., Skagen, K., Skrøwset, S., \& Thue F. W. (2016). Om lærerrollen Et kunnskapsgrunnlag. Fagbokforlaget. http://urn.nb.no/URN:NBN:no-nb_digibok_2021072948113

Direktoratet for byggkvalitet. (2017). Byggteknisk forskrift (TEK17) med veiledning. https://dibk.no/byggereglene/byggteknisk-forskrift-tek17/

Fairclough, N. (2003). Analysing Discourse : Textual Analysis for Social Research. Routledge. https://doi.org/10.4324/9780203697078

Goodlad, J. I., Klein, M. F., \& Tye, K., A. (1979). The Domains of Curriculum and Their Study. In Curriculum Inquiry. The study of Curriculum Practice (pp. 43-76). McGraw-Hill Book Company.

Grunnskolerådet. (1972). Forming, rom og utstyr (Informasjonshefte nr. 6). Universitetsforlaget. https://urn.nb.no/URN:NBN:no-nb_digibok_2009010704089

Grunnskolerådet. (1979). ERFA om skolebygg Planlegging og utforming av skolebygg Grunnskolen. http://urn.nb.no/URN:NBN:no-nb_digibok_2008060200086

Grunnskolerådet. (1983). ERFA om skolebygg. Fagarealer i grunnskolen. http://urn.nb.no/URN:NBN:nonb_digibok_2014040905040

Grunnskolerådet. (1984). Forming. Innstilling fra en arbeidsgruppe. http://urn.nb.no/URN:NBN:nonb_digibok_2013100206075

Grunnskolerådet. (1991). Handlingsplan for styrking av de estetiske fagene i skolen: inntrykk - uttrykk - avtrykk. https://www.nb.no/nbsok/nb/d9cf59eb26e23858d2cbd88e2f9221f5?index=11\#0

Haabesland, A. Å. \& Vavik R. (2004). Kunst og håndverk - hva og hvorfor. Fagbokforlaget. http://urn.nb.no/URN:NBN:no-nb_digibok_2013120306117

Hansen, B. H. (2015). Trearbeid og treverksteder i grunnskolen: Skolelederes verdsetting og prioritering sett opp mot tradisjon og fornyelse i faget Kunst og håndverk [Masteravhandling, Høgskolen i Oslo og Akershus]. ODA. https://oda.oslomet.no/oda-xmlui/handle/10642/2712

Hellkås T. (1959). Rom for sløyd- og tegneundervisning. I M. Dalaker \& A. Bastiansen (Red.), Skolebygging: kurs ved NTH 1958 (s. 93-98). NTH. http://urn.nb.no/URN:NBN:no-nb_digibok_2017020908019

Helsedirektoratet. (2014). Miljø og helse i skolen Veileder til forskrift om miljørettet helsevern i barnehager og skoler. https://www.helsedirektoratet.no/veiledere/miljo-og-helse-i-skolen/pdf-versjon

Håberg K. R., Johanson L., Nielsen L. M. \& Retvik J. (1997). Mønster på vandring. Tell forlag.

Kjosavik, S. (2003). Fra forming til kunst og håndverk fagutvikling og skolepolitikk 1974-1997 (HiT skrift nr. 5/2003). Høgskolen i Telemark. http://hdl.handle.net/11250/2439167

Kolsrud, O. (2008) Rekonstruksjon og reform. Regjeringskontorene 1945-2005. Universitetsforlaget. http://urn.nb.no/URN:NBN:no-nb_digibok_2013060305011

KUD. (1922). Normalplan for landsfolkeskolen. J.M. Stenersen forlag. http://urn.nb.no/URN:NBN:nonb_digibok_2016101929003

KUD. (1939). Normalplan for byfolkeskolen. H. Aschehoug \& co. http://urn.nb.no/URN:NBN:nonb_digibok_2017062307152 
KUD. (1946). Typeplaner for skolehus i bygdene. Lovføresegner, administrative direktiver og rettleiing, typeplaner. http://urn.nb.no/URN:NBN:no-nb_digibok_2017010648013

KUD. (1947a). Lov om folkeskolen i kjøpstædene (av juli1936). Med forklaring av Kirke-og undervisningsdepartementet. http://urn.nb.no/URN:NBN:no-nb_digibok_2016121548261

KUD. (1947b). Normalplan (Mønsterplan) for landsfolkeskulen. H. Aschehoug \& co. https://www.nb.no/nbsok/nb/63ab91c9d9627082e506d43f784d7a83?lang=no\#0

KUD. (1960). Læreplan for forsøk med 9-årig skole. Aschehoug. http://urn.nb.no/URN:NBN:nonb_digibok_2008051904019

KUD. (1974). Mønsterplan for grunnskolen. Aschehoug. http://urn.nb.no/URN:NBN:nonb_digibok_2008052804017

KUD. (1978). Rundskriv F-100/78. Arkivet Kunnskapsdepartementet.

KUD. (1987). Mønsterplan for grunnskolen. Aschehoug. http://urn.nb.no/URN:NBN:nonb_digibok_2007080200101

KUF. (1997). Læreplanværket for den 10. årige grunnskolen. https://www.nb.no/nbsok/nb/f4ce6bf9eadeb389172d939275c038bb\#0

Lov om Folkeskolen i kjøpstederne. (1889). http://urn.nb.no/URN:NBN:no-nb_digibok_2006112001026

Lov om Folkeskolen paa landet. (1889). http://urn.nb.no/URN:NBN:no-nb_digibok_2006112001026

Lov om Folkeskolen i kjøpstædene. (1936). http://urn.nb.no/URN:NBN:no-nb_digibok_2008041601027

Lov um folkeskulen på landet. (1936). http://urn.nb.no/URN:NBN:no-nb_digibok_2012092705085

Nielsen, L. M. (2019). Fagdidaktikk for Kunst og håndverk. I går, i dag, i morgen (2. utg.). Universitetsforlaget.

NOU 1975: 40 (1975). Planlegging og utforming av undervisningsbygg. Kirke og undervisningsdepartementet. https://www.nb.no/items/URN:NBN:no-nb_digibok_2008121500059

Selvåg, O. (1959). Skoler og økonomi. I B.L. Mohr (Red). Skolebygging: kurs ved NTH 1958 (s. 149-157). NTH. http://urn.nb.no/URN:NBN:no-nb_digibok_2017020908019

Sirvåg, T. (1959). Proposisjon om lov om folkeskolen (Ot. Prp. Nr.30, 1958) og spørsmålet om skoleutbygging og romkrav. M. Dalaker \& A. Bastiansen (Red.), Skolebygging: kurs ved NTH 1958 (s. 55- 61). NTH. https://www.nb.no/items/URN:NBN:no-nb_digibok_2017020908019

Skrede, J. (2017). Kritisk diskursanalyse. Cappelen Damm Akademisk.

Tvedt, J.P. (2018). Kreative rom, eller rom for kreativitet: en studie av hvordan rom for kunst og håndverk utformes i ungdomsskolen. [Masteravhandling, NMBU] https://nmbu.brage.unit.no/nmbuxmlui/handle/11250/2558175

Underthun, K. (2003). Rom for kunst og håndverk: en studie av de estetiske og funksjonelle aspekter ved rom for kunst og håndverk på nybygde skoler. [Hovedfagsavhandling]. Høgskolen i Oslo Avdeling for estetiske fag.

Utdanningsdirektoratet. (2020). Læreplan i kunst og håndverk (KHV01-02). https://www.udir.no/lk20/khv01-02 